\title{
Die opstanding van Jesus as kulminerende genesings- handeling in Johannes
}

\author{
$\mathrm{J} \mathrm{Kok}^{1}$ \\ (Universiteit van Pretoria)
}

\section{ABSTRACT \\ The resurrection of Jesus as the culminating healing act in John}

John views the death and resurrection of Jesus as an inseparable unity (cf 10:17-18). In this article it is then argued that the resurrection of Jesus in John could be understood as a Johannine

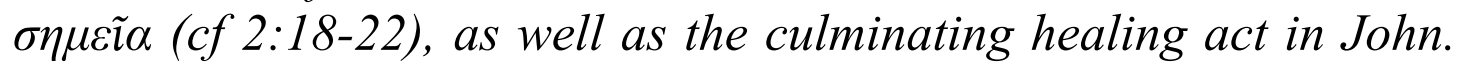
It also serves as the most important $\sigma \eta \mu \varepsilon \tilde{i} \alpha$ against which the other

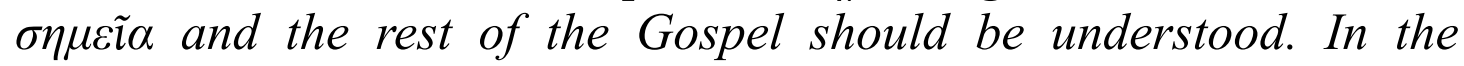
resurrection as the culminating healing act, John's Jesus restores his own brokenness (and death) and proves that He is the source of life (cf 1:4; 11:25), also by bringing healing and restoration to the spiritually blind (cf 9:40-41; 12:40). This article is a result of the writer's PhD thesis ${ }^{2}$.

\section{INLEIDING}

Enkele opmerkings ten opsigte van die metodologie word kortliks uitgespel om $u$ as leser te help om die argument beter te kan volg. In hierdie artikel word geargumenteer dat die opstanding van Jesus in Johannes beskou kan word as die kulminerende genesingshandeling van God. In die proses word daar eerstens in gesprek getree met geleerdes soos Van Belle (2006) wat nie van mening is dat die opstanding as " $\mathrm{n}$ Johannese $\sigma \eta \mu \varepsilon \tilde{\alpha} \alpha$ beskou word nie. Om die beoogde argument te versterk word daar in die tweede plek aangedui dat ' $n$ onlosmaaklike teologiese verband tussen die kruis en die opstanding in die teks van Johannes bestaan. Vervolgens word daar geargumenteer waarom die opstanding as 'n genesingshandeling beskou kan word en hoe die kategorie van bekering gekoppel word aan die gedagte van genesing of restourasie. Ten einde hierdie doelwit te bereik word daar aangetoon dat die teks van Johannes self dit op hierdie wyse beskryf, dat hierdie gedagte reeds in die $\mathrm{Ou}$ Testament voorkom en dat Johannes hierdie verband trek. Laastens

1 Dr Kobus Kok is ' $n$ navorsingsassosiaat in die Departement Nuwe Testament aan die Universiteit van Pretoria.

2 Sien Kok (2008). 
word geargumenteer dat die opstanding in Johannes nie net die eskatologiese era van die Gees laat aanbreek nie, maar uiteindelik ook beskou kan word as die kulminerende genesingshandeling in die Universele Goddelike Narratief van Johannes se evangelie.

\section{DIE OPSTANDING AS SEMEIA?}

In 'n onlangse artikel ${ }^{3}$ verwys Van Belle (2006) na die resente toespraak in sy "presidential address of the recently held Colloquium Biblicum Lovaniense" aangaande "The Death of Jesus of the Fourth Gospel". In hierdie artikel vra hy die vraag, "...[W] hether it could be agreed that the cross was by distinction the sign in the Gospel of John?" Anders gestel wil Van Belle weet of daar gepraat kan word van die "kruis as teken" in die konteks van Johannes se "theology of

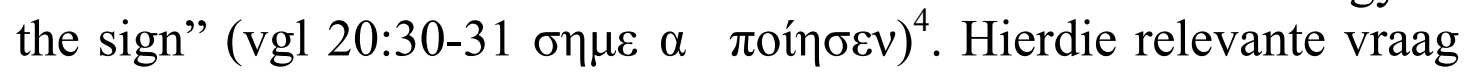
word gestel in ' $n$ konteks waar dit na sy mening nie ' $n$ populêre beskouing onder geleerdes is nie. Hy merk in hierdie konteks op: "It appears that the majority of exegetes do not defend reading in the "to perform signs' the plausibility that John is also referring to the passion and death of Christ". In sy toespraak en in die artikel onder oë argumenteer Van Belle (2006:5) dat die kruis inderdaad as die kulminerende teken in die evangelie beskou kan word ${ }^{5}$. Van Belle

3 Die tema van die artikel lui: "Glorification Through Incarnation and Humiliation in the Fourth Gospel." Die tema van die toespraak by die Colloquium Biblicum Lovanience het gehandel oor " The Death of Jesus of the Fourth Gospel".

4 In Johannes 20:30-31 word die doel van die evangelie duidelik deur die

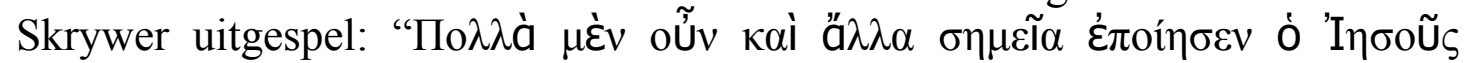

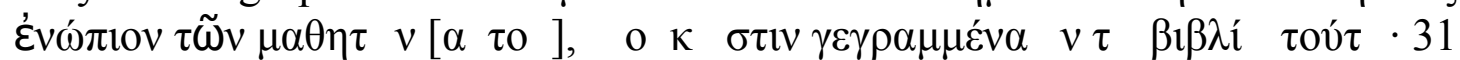

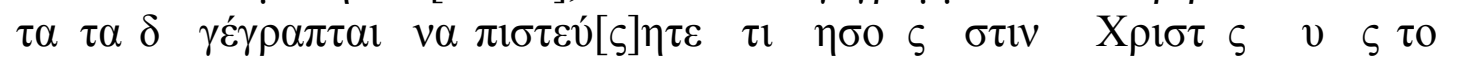

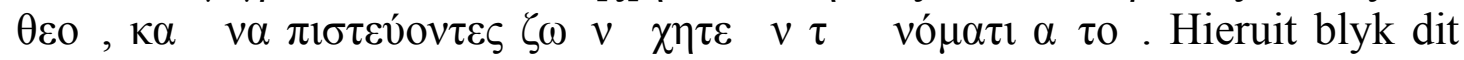
duidelik dat dat daar baie ander verhale is wat hy kon vertel om sy doel te bereik, naamlik dat mense kan glo dat Jesus die gestuurde Seun van God is en deur te glo die ewige lewe kan hê. Johannes het egter 'n seleksie gemaak uit al die beskikbare verhale tot sy beskikking en dit so angebied dat dit die betrokke doel van sy evangelie kan bereik (Köstenberger 2004:581; Carson 1991:660-661).

5 Van Belle verwys kortliks na die volgende voorbeelde: Hy argumenteer dat dieselfde woordeskat in die passie-narratief as in die wonderverhale gebruik

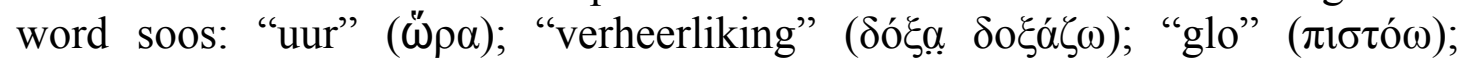
"sien". Tweedens word die passie-narratief ten nouste verbind met "n diskoersteks. Die lyding en dood van Jesus word deur die voorafgaande afskeids- 
verhef die kruisgebeure in die evangelie en ontwikkel nie die rol van die opstanding in die uiteindelike betekenis van die kruis nie. Hy verbind die teken van die kruis met lewe, maar bring nie die teken van die opstanding in verband daarmee nie. Teenoor Van Belle is dit my opinie dat die teken van die kruis juis lewe-skeppende betekenis kry in die lig van die teken van die opstanding as kulminerende genesingshandeling ${ }^{6}$ (vgl 10:17-18).

Die volgende patroon (heuristiese kategorieë) is te bespeur in die wondertekens $\left.{ }^{7} .{ }^{*} 1\right)$ Daar is telkens ' $\mathrm{n}$ negatiewe materiële komponent wat verteenwoordigend is van ' $\mathrm{n}$ verlies of gebrokenheid, krisis en disoriëntasie situasie van een of ander aard, soos die aanwesigheid van dood en die verlies van kwalitatiewe lewensmoontlikhede in die geval van die genesingswonders; *2) Te midde van hierdie skynbare uitsigloosheid tree Jesus as transformasie agent na vore en transformeer die materiële deur die herskepping van kwalitatiewe lewensmoontlikhede; Die disoriëntasie situasie maak plek vir 'n reoriëntasie situasie *3) Telkens wys dit heen na 'n groter analogiese geestelike waarheid waarvolgens die gebrokenheid herskep sal word in geestelike lewensmoontlikhede.

In die konteks van al die ander tekens $(\sigma \eta \mu \varepsilon \tilde{\alpha} \alpha)$ is dit duidelik waarom Van Belle se konseptering van die kruis as teken nie tot sy

diskoers en die Hoëpriester Gebed $(13: 1-17,25)$ in konteks geplaas. Derdens gebruik die skrywer dieselfde literêre tegnieke in die passienarratief as wat in die wonderverhale gebruik word naamlik: 1) Beklemtoning van die materiële wêreld as uitdrukking van Jesus se inkarnasie; 2) Beklemtoning van Jesus se bonatuurlike vermoëns; 3) Die aanwesigheid van dieselfde Christologiese titels $\mathrm{nl}$ Messias of Christus, die ware koning en profeet asook die Seun van God en Seun van die Mens. Hierdie beklemtoning van die literêre ooreenkomste tussen die wonderverhale en die passienarratief is volgens Van Belle net een van die redes wat die sogenaamde "Louvain Hypothesis" aanvoer.

6 Van Belle se kollega, Petrus Maritz (Van Belle 2006:10), wys tereg daarop dat Johannes se stilistiese woordspel in kombinasie met sy dramatiese vertragings-tegniek lig op die onderwerp van die kruis as teken kan werp (2006:10). Myns insiens geld dit ook vir die opstanding as teken. Hier gaan ek poog om Maritz en Van Belle se postulerings in my eie op te neem en te illustreer waarom die teken van die kruis van Van Belle nie los van die teken van die opstanding verstaan kan word nie.

7 Sien Kok (2008) vir 'n meer deeglike verduideliking van hierdie patroon waarin die verskillende genesingsverhale in detail bespreek word. 
reg kan kom sonder dat die rol van die opstanding verdiskonteer is nie. Laat ek verduidelik:

Die kruisdood is ' $n$ voorbeeld van verlies van lewensmoontlikhede, gebrokenheid en uitsigloosheid. Opsigself is dit geen teken nie, soos wat die dood van Lasarus geen teken $(\sigma \eta \mu \varepsilon \check{\alpha} \alpha)$ opsigself is nie. Die Lasarus-verhaal word $\sigma \eta \mu \varepsilon I ̃ \alpha$ sodra die transformerende lewe-skeppende realiteit ingetree het en hy opgewek word uit die dood. Die blinde man se blindheid is geen $\sigma \eta \mu \varepsilon \tilde{\alpha} \alpha$ opsigself nie. Die blindheid van geboorte af word eers $\sigma \eta \mu \varepsilon \tilde{\alpha} \alpha$ die oomblik as Jesus sy blindheid restoureer en sy uitsigloosheid transformeer in lewe-skeppende potensialiteit. Net so kan daar geargumenteer word dat die kruis eers $\sigma \eta \mu \varepsilon \tilde{\alpha} \alpha$ word in die lig van die transformerende lewe-skeppende realiteit van die opstanding, wanneer die gebrokenheid genees word en die uitsigloosheid vervang word met nuwe lewe. Die kruis maak dus net sin deur die bril van die opstanding (vgl 10:17-18 wat hier onder bespreek sal word). Wanneer daar in die lig van die opstanding na die kruisgebeure gekyk word, word die kruis se uitsigloosheid getransformeer in ' $n$ simbool van lewe. Die kruis word belangrik aangesien die kruis die instrument word waardeur die heerlikheid geopenbaar word. Wie die kruis sien, sien die leë graf en die bewys van kwalitatiewe lewensmoontlikhede binne die familie van die Koning.

In bogenoemde argumentasie kan die gevaar bestaan dat die argument op die vlak van "interpretasie" berus en nie getrou is aan Johannes se teologie en sy teks nie. Die belangrike vraag wat met ander woorde verdiskonteer moet word, is of die teks self die kruisgebeure en die opstanding as 'n onlosmaaklike eenheid beskou. In die gedeelte wat volg gaan die vorige argumentasie verder verdiep word deur te argumenteer dat die Johannese teks self inhoudelik die kruisdood en die opstanding nie los van mekaar sien nie.

\section{DIE ONLOSMAAKLIKE TEOLOGIESE VERBAND TUSSEN DIE KRUIS EN DIE OPSTANDING IN JOHANNES}

\subsection{Inleiding}

Vir Johannes is die kruis en opstanding teologies onlosmaaklik aan mekaar verbind (vgl later die bespreking van 10:17-18) ${ }^{8}$. Kysar

8 Van der Watt (2000a:ad loc) merk op: "For him the cross, burial, resurrection and even the outpouring of the Spirit are different facets of one 
(1986:163-164) stem hiermee saam en merk op: "In John the crucifixion and resurrection are a single event, inseparable bound together". Aan die kruis word Jesus verheerlik en word sy ware identiteit geopenbaar (Schnelle 1998:157) ${ }^{9}$ (8:28) en trek Hy die mense wat aan Hom behoort na Hom toe $\left(12: 31-32^{10}\right.$; $3: 14-15$; sien Schnackenburg 1971:492-493; Gnilka 1983:29; Schnelle 1998:74) ${ }^{11}$. Maier (1984:378) in sy kommentaar op 8:28-29 is korrek as hy die volgende opmerk:

Mann muss freilich auch sehen, dass "Erhöhen" ein doppelsinniger Ausdruck ist. Es bedeuted nicht nur "Hinaufhängen ans Kreuz", sondern auch "Erhöhen" zu Gott in götliche Machstellung. Letzteres geschieht durch Auferstehung und Himmelfahrt, die also ebenfalls mit dem 'Erhöhen' prophezeit sind.

In sy kommentaar op 2:18-22 ondersteun Houwelingen (1997:87) ook die teologiese eenheid van die dood en die opstanding van Jesus en merk op: "Het afbreken en herbouwen duidde op het doden én het opwekking van zijn lichaam"12. Vir Johannes is die kruis nie " $n$

important integrated event (which we refer to as the 'cross event/s') which have changed the course of history. These events are treated in a close relationship with each other, without collapsing the different events into undistinguishable whole." Wilckens (1998:340-341) gebruik woorde soos "ineinsgesehen" en "ineinsfallen" wanneer hy oor die verhouding tussen die kruis, opstanding en hemelvaart besin.

9 Kysar (1986:140) merk op: "The cross is the decisive event which manifests Jesus' true identity." Schnelle (1998:157) is dus korrek as hy daarop wys dat: "Die Erhöhung hat für Johannes Offenbarungscharakter; sie zeigt, dass Jesus der Sohn Gottes ist, weil sich am Kreuz die Liebe Gottes zur Welt offenbart" (vgl Joh 3:16).

10 Maier (1986:42) merk op: "Über die Konsequenz seiner Auferstehung sagt Jesus: 'Und ich, wenn ich von der Erde erhöht werde, werde alle zu mir ziehen. Das Erhöht werden von der Erde' is Tod und Auferweckung in einem" $(\operatorname{vgl} 3: 14 ; 8: 28)$.

11 Vir Schnackenburg (1971:493) is die kruis die plek waar Jesus se heerlikheid openbaar word: "Das Kreuz ist für Joh schon so sehr Ort der Verherrlichung und Beginn der Heilsherrschaft Jesu (vgl 19, 37), dass Jesus nicht nur zu sich ans Kreuz, sondern auch in den himmlischen Bereicht zieht".

12 Sien Köstenberger (2004:307-308) wat in sy bespreking van 10:17-18 nie die onlosmaaklike verband tussen die dood en opstanding van Jesus genoegsaam bespreek nie. 
skandalon (vgl 1 Kor 1:18; Hand 17:32) soos by Paulus nie. Vir Johannes is die kruis net soos by die genesingshandelinge " $\mathrm{n}$ semeia $(2: 18)$ wat heenwys na ' $n$ groter geestelike waarheid ${ }^{13}$. Die kruis ${ }^{14}$ word vir Johannes in die dampkring van $\delta$ ó $\xi \alpha$ ingetrek (vgl ook 3:14; $8: 28 ; 12: 23-24,32 ; 13: 31 ; 17: 1$; sien Schnackenburg (1990:352), afhangende van hoe mens daarna $\mathrm{kyk}^{15}$. Volgens Van der Watt (2000a) kan die kruis in Johannes op twee maniere geïnterpreteer word $^{16}$ :

1 Deur die vleeslike oë van ongeloof ${ }^{17}$.

2 Of deur geestelike oë van geloof ${ }^{18}$.

In Johannes 3:6 sê Jesus vir Nikodemus dat dit wat uit die vlees gebore is, vleeslike resultate oplewer en dit wat uit die gees gebore is, geestelike resultate oplewer $(3: 6$; vgl ook $3: 31 ; 8: 23 ; 17: 14)$. Dit impliseer natuurlik dat indien die mens net in terme van menslike beperkinge dink (vleeslik), hy gebeure alleen deur die bril van die vlees sal kan sien (Van der Watt 2000a; Gnilka 1983:27; Brown

13 Vir ' $n$ bespreking rondom die verhouding tussen die passie-narratief van die sinoptiese evangelies en die Johannesevangelie, sien Green (1988:105).

14 Sommige geleerdes argumenteer dat Johannes nie soos by Paulus die verlossings- en rekonsiliasie waardes van die kruis beklemtoon nie. Johannes se kruisteologie word volgens hulle eerder ontwikkel rondom die temas van Jesus se koninklike mag, verheerliking, die kruis as eskatologiese plan van God en die kruis as liefdevolle diens (vgl ook 10:15).Vir inligting oor die teologie van die kruis sien Knöppler (1994).

15 Sien ook Bultmann (1984) wat die kruis-gebeure binne die inkarnasie motief integreer. Sien ook Rahner (1998:62).

16 Hier word op die basiese argumentering van Van der Watt (2000a) ingespeel en daarom gaan ek nie telkens na hom verwys nie.

17 Die Jode staan antagonisties teenoor Jesus wat die kultiese gebruike van die tyd volgens hulle verontagsaam (vgl 5:18; 2:13-22). Kyk Lincoln (2005:198); Ridderbos (1997:15); Schnackenburg (1990:213); Köstenberger (2004:266); Maier (1986:291) en Schnelle (1998:279).

18 Deur die geestelike oë van geloof kry die kruis 'n totale nuwe betekenis. Deur die oë van geloof word die kruis in Johannes nie as $\sigma \kappa \alpha ́ v \delta \alpha \lambda o v$ beskou nie, maar as $\delta$ ó $\xi \alpha$. of verheerliking. Hier bo is geargumenteer dat die kruis as teken net verheerliking kan beteken in die lig van die opstanding. Om hierdie argument te versterk moet daar egter gekyk word of die Johannesevangelie in die teks self teologies die kruis en die opstanding (ook die hemelvaart) onlosmaaklik aan mekaar verbind. 
1984:138; Ridderbos 1997:124-125). Johannes maak dit egter duidelik dat daar ook 'n ander perspektief is, naamlik om deur die bril van die gees, of geloof te kyk (Carson 1991:188). Deur die geestelike bril van geloof word die Christus gebeure binne die raamwerk van die geestelike realiteit en die Universele Goddelike Narratief $^{19}$ geïnterpreteer ${ }^{20}$. Brown (1984:138) wys daarop dat "[T] he tactic of the Johannine discourse is always for the answer to transpose to a higher level; the questioner is on the level of the sensible, but he must be raised to the level of the spiritual". Dit skep vir Johannes se Jesus dan telkens die geleentheid om, deur middel van die tipiese misverstand as tegniek aan te wend, te verduidelik hoe die ware geestelike realiteit daarna uitsien..

\subsection{Jesus se eie refleksie oor sy dood in Johannes}

Binne die narratologiese raamwerk van Johannes reflekteer Jesus verskeie kere oor sy eie dood (sien byvoorbeeld 3:14-15; 8:28-29; $10: 17-18 ; 12: 23-26,31-33 ; 14: 30-31 ; 16: 31-33)$. Op hierdie wyse verkry die implisiete leser ideologiese perspektiewe om uiteindelik die dood ${ }^{21}$ en die opstanding van Jesus sinvol binne ' $n$ bepaalde

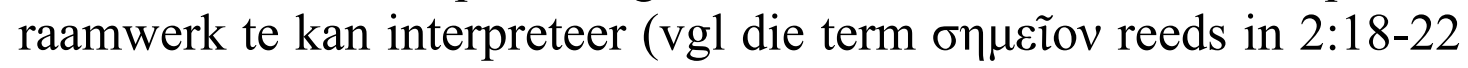
en die verband met Jesus se dood en opstanding). By nadere ondersoek blyk dit dat daar eksplisiete assosiatiewe verbande in die

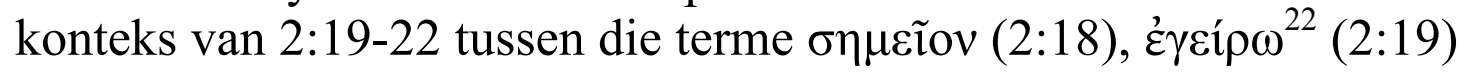

19 Volgens Reinhartz (1992; Kyk ook 2001) kan Johannes op ten minste drie vlakke gelees word: die historiese (Jesus), die ekklesiologiese (Johannese gemeenskap) en die kosmologiese vlakke. Die UGN of Universele Goddelike Narratief is die meta-narratief wat op makro-vlak afspeel.

20 Sien Dodd (1960:373). Wilckens (1998:67) wys verder daarop dat hierdie "dualistische Sprache" in duidelike kategorieë uitgedruk word: "Der Geist ist "von oben', er hat seinen Herkunftsbereich im Himmel (vgl v12); und wo er in einem irdischen Menschen wirkt, wird dieser durch seine Kraft in seinem ganzen Sein so in die 'obere' Herkunft des Geistes hineingenommen, dass er völlig verändert, neu geworden, eben 'von oben her geboren' ist".

21 Köstenberger (2004:266) merk tereg op dat dit in die tweede tempel tydperk algemeen aanvaar was dat dood die resultaat was van die Satan se inisiatief (Kyk Wisdom 2:23-24; Sirag 25:24).

22 Swanson (1997) wys op die semantiese gebruik van die term in verskillende Nuwe Testamentiese Kontekste. Hieruit is dit duidelik dat die assosiatiewe betekenis van die woord dikwels met restourasie in verband

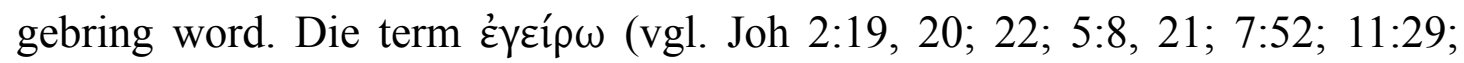
$12: 1,9,17 ; 13: 4 ; 14: 31 ; 21: 14$ ) is myns insiens 'n tegniese term wat veral deur 


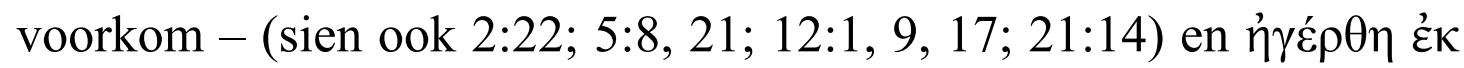

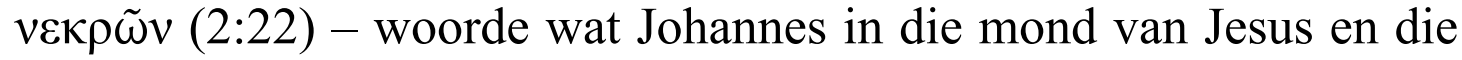
post opstandings-interpretasie en verwysingsraamwerk van die dissipels plaas en waar die opstanding direk as ' $\mathrm{n} \sigma \eta \mu \varepsilon i \tilde{o} v$ in Johannes beskryf word (vgl Köstenberger 2004:110-111; Morris 1995:179):

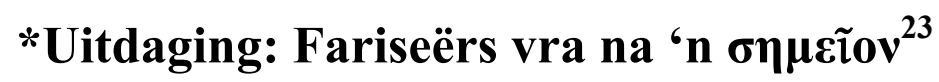

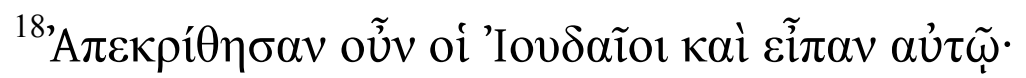

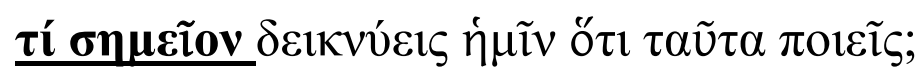

*Jesus antwoord: Afbreek ${ }^{24}(\lambda \tilde{\sigma} \sigma \alpha \tau \varepsilon)$ én restourasie $(\varepsilon \dot{\gamma} \varepsilon \rho \tilde{\omega})$ van sy liggaam (tempel) as teken

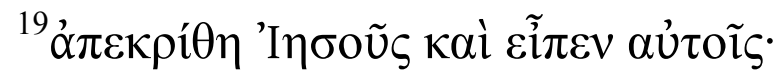

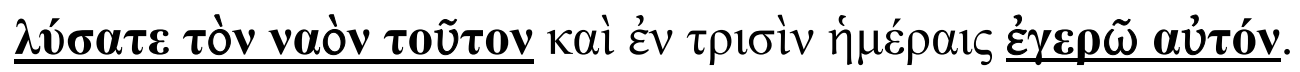

*Misverstand: Jode Interpreteer Jesus se woorde vleeslik (vgl 3:36) ${ }^{25}$

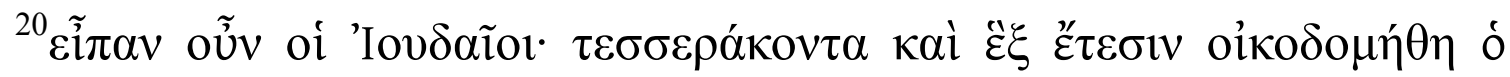

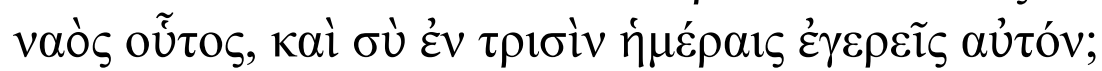

*Regstelling/Openbaring: Tempel verwys na Jesus se liggaam

Johannes gebruik word om opwekking uit die dood mee te beskryf, en met die genesing van die lam man gebruik word in die konteks van Jesus se woorde wat lewe skep en restourasie bring vir 'n man wat al jare lank gebrokenheid ervaar. Dit is dan ook dieselfde term wat gebruik word in 12:1, 9 en 17 vir die opwekking van Lasarus uit die dood en in 5:21 om te verwys na Jesus as die een wat mense vanuit die dood na die lewe sal bring.

23 Morris (1995:173-174) wys daarop dat dit die Joodse verwagting was dat die Messias bepaalde tekens sou doen (vgl Joh 7:31; sien Barrett 1978:199; Moloney 1998:81).

24 Kyk Morris (1995:174). Vgl Hand 6:14; 7:48; 17:24) met spesifieke

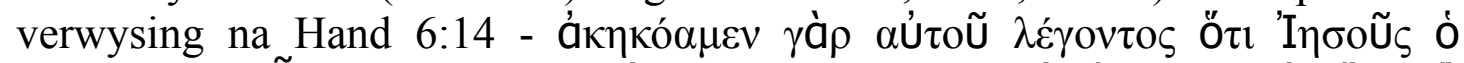

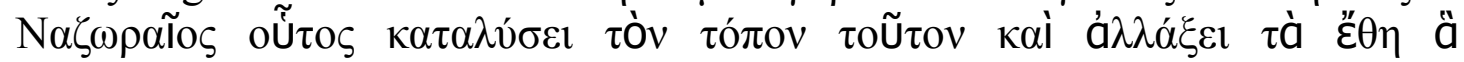

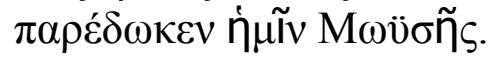

25 Wengst (2000:112-113) is korrek as hy daarop wys dat hierdie gedeelte (2:18-22) verstaan word teen die agtergrond van die voorafgaande reiniging van die tempel, en die Jode se uitdaging aan Jesus om met 'n wonderteken sy outoriteit te bewys (sien Barrett 1978:199; Moloney 1998:81) aan die een kant; en die volgende teksgedeelte wat hy indeel onder 2:23-3:3:21 onder die opskrif: "Die Geburt aus dem Geist" (Wengst 2000:112-113). 


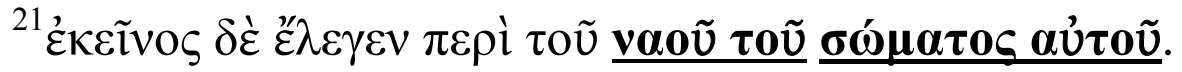

*Reorientasie: Korrekte Geestelike Interpretasie van Jesus se woorde

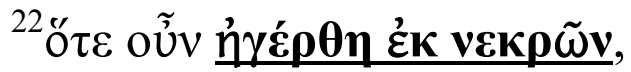

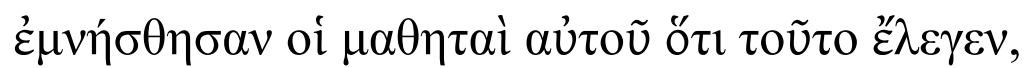

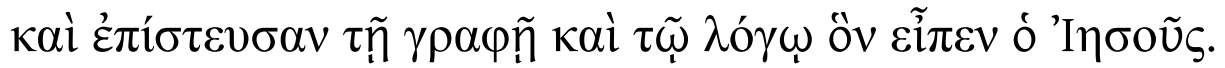

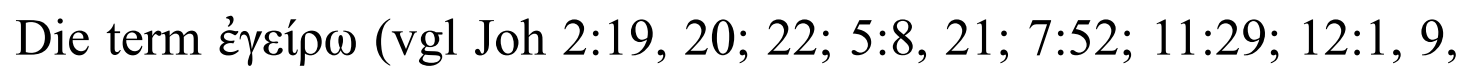
$17 ; 13: 4 ; 14: 31 ; 21: 14$ ) is myns insiens ' $n$ term wat veral deur Johannes gebruik word om opwekking uit die dood mee te beskryf (vgl 2:19-22; 5:21; 12:1, 9, 17; 21:14). In die verhaal van die

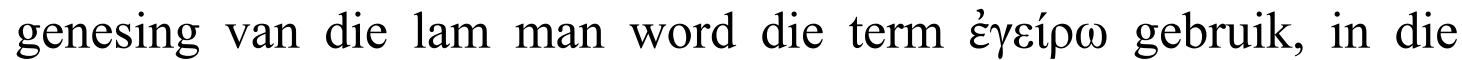
konteks van Jesus se woorde wat lewe skep en restourasie bring vir

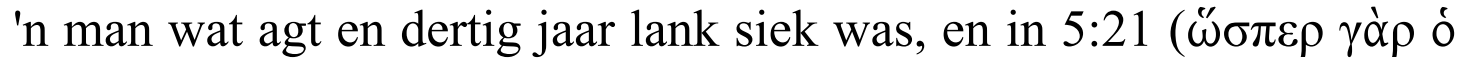

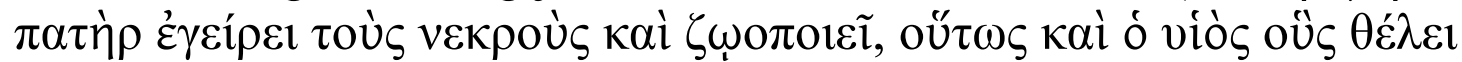
$\zeta(\omega 0 \pi$ oเعi.) om te verwys na Jesus as die een wat mense vanuit die dood na die lewe sal bring (vgl 5:24). Dit is dieselfde term wat gebruik word in 12:1, 12, 9 en 12:17 vir die opwekking van Lasarus uit die dood. In die konteks van 2:18-22, wat hier bo uiteengesit is, vra die Joodse leiers vir Jesus 'n $\sigma \eta \mu \varepsilon \tilde{i o v}$, en dan maak Johannes dit

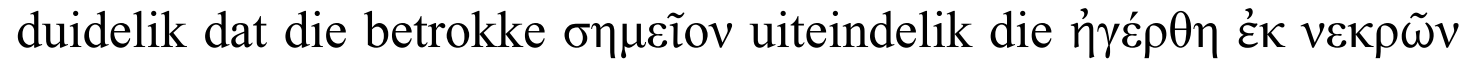
(2:22) - die opwekking van Jesus uit die dood sal behels.

Die feit dat die Jode nie wedergebore is nie, veroorsaak dus dat hulle deur vleeslike oë van ongeloof na Jesus kyk en nie die woorde van Jesus en die implikasie daarvan begryp nie (sien Carson 1991:181; Ridderbos 1997:117; Schnelle 1998:69). Johannes verduidelik dat Jesus se woorde eintlik figuurlik geïnterpreteer moet word en dat die afbreek en opbou van hierdie tempel in werklikheid na sy liggaam $(2: 21-\sigma \omega ́ \mu \alpha \tau o \varsigma \alpha u ̉ \tau o \tilde{v})$ verwys. Die enigste ander keer waar die term $\sigma \omega ́ \mu \alpha$ in Johannes gebruik word, verwys dit na die gebroke (dooie) liggaam van Jesus (vgl 19:38, 39; 20:12; sien Schnackenburg 1990:357; Barrett 1978:201). 


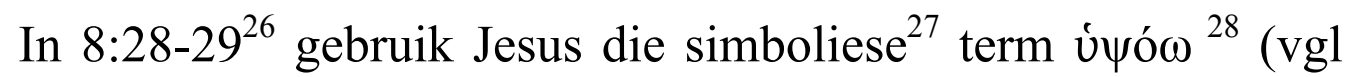
die aktiewe v́ $\psi \omega ́ \sigma \eta \tau \varepsilon$ in 8:28 teenoor die passief $v \psi \omega \theta \tilde{\eta} v \alpha \iota$ in 3:14) om na die kruis te verwys (Busse 2002:166-167; Bultmann

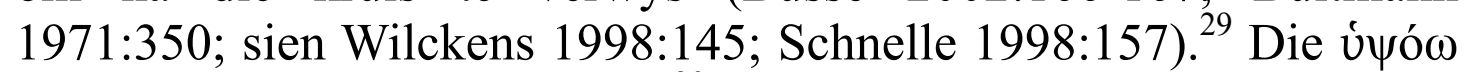

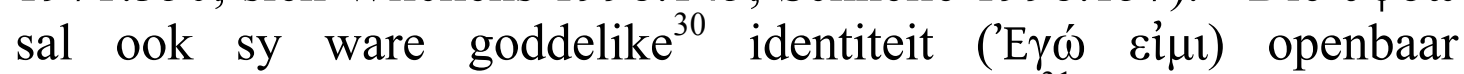

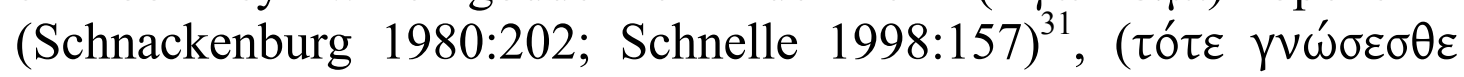

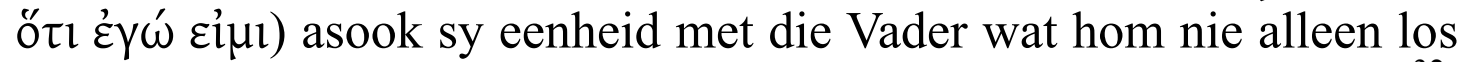

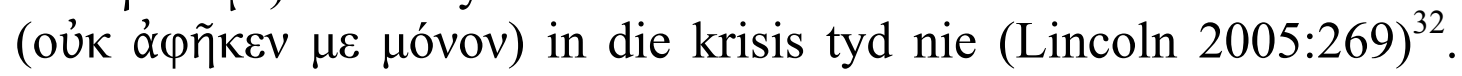
Die Vader is dus aktief teenwoordig by Jesus in en deur die kruisgebeure en los die Seun nie alleen soos in die Sinoptiese weergawe nie (vgl Mark 14:50; 15:34; sien Schnelle 1998:157). Al word die dissipels tydelik alleen gelos (vgl. 16:32), is die Vader

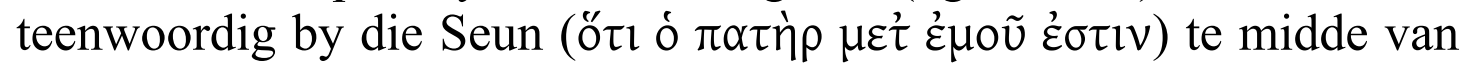

26 Volgens Van der Watt (2000a) kom hierdie gedeelte voor binne die basiese raamwerk van " $n$ forensiese konteks. Dit volg op die woorde van Nikodemus 7:50-52, en word aangedui deur die gebruik van terme soos krisis "oordeel" $(7: 51 ; 8: 15,16,26,50)$ en marturia "getuienis" $(8: 13,14,17,18)$. Verder speel hierdie gedeelte ook af teen die agtergrond van die vraag oor Jesus se indentiteit (8:25) en die reaksie van die Jode wat Jesus wil stenig (8:59).

27 Barrett (1978:214,343) verwys na die dubbele betekenis van hierdie werkwoord. Dit is baie interessant om daarop te let dat Numeri 21:8-9 waar Moses die slang hoog op 'n paal moes sit ook in die konteks van lewe, redding en genesing gegiet word. Barrett (1978:214) merk op: "His lifting up will result not only in glory for himself but also in healing for mankind".

28 Jesus verwys na die Seun wat verhoog sal word op minstens drie plekke (sien Joh 3:14; 8:28; 12:32,34).

29 Myns insiens neem dit nog steeds nie die Goddelike $\delta \varepsilon \tilde{\imath}$ weg nie, inteendeel - dit is alles deel van die Vader se plan (vgl 3:16;14:31; 16:32). Kyk Schnackenburg (1971:256).

30 Sien Brown (1972:348).

31 Schnelle (1998:157) merk op: "Erst wenn Jesus durch seine Kontrahenten am Kreuz erhöht wird, werden auch sie seine Person erkennen". Sien Carson 1991:345. Sien ook Neyrey (1996:113-137, 119-120) oor eer en skande in die Johannese passie-narratief.

32 Schnackenburg (1971:187) merk op: "Das Motiv der Verlassenheit Jesu gehört zum Leidensweg des Menschsohnes im Mk-Ev, wo alle Jünger fliehen $(14,50)$, und es steigert sich dort bis zur Gottverlassenheit am Kreuz $(15,34)$. Das erste nimt die joh. Schule auf, das zweite kann sie aus ihrer Christologie nicht zugeben. Der joh. Jesus is nicht allein, der Vater verlässt ihn nicht, sondern ist stets mit ihm, auch in der dunkelsten Studen". 
die kruisgebeure $^{33}$ (Van der Watt 2000a). So word die kruis dan juis die fokus-punt wat bewys dat die Vader intens by die gestuurde Seun betrokke is (vgl 16:27; 17:7, 25; sien ook 14:18-21).

Die kruis word in die evangelie ook beskou as die moment waar die oordeel oor hierdie wêreld voltrek word en waar die heerser van hierdie wêreld uitgegooi sal word (12:31-33; sien Köstenberger 2004:382) en die kinders van God na Hom getrek ${ }^{34}$ sal word (Lincoln 2005:352; Schnelle 1998:204-205; Kysar 1986:199). Die inisiatief kom in die eerste plek van die Vader af wat die Seun

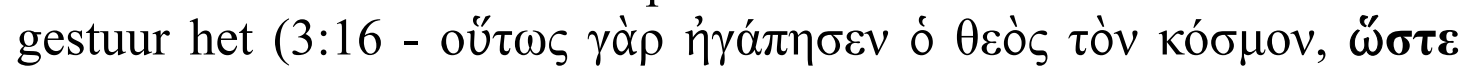

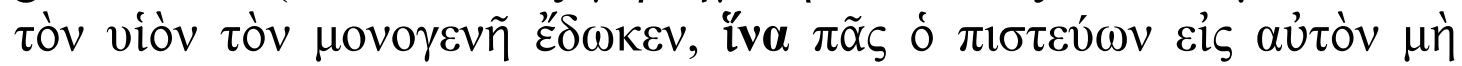

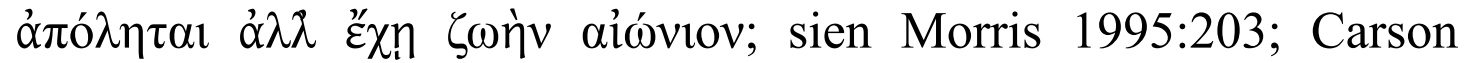
1991:205) en word in noue vennootskap tussen die Vader en die Seun uitgevoer (sien Witherington 1995:175; Joh 8:16, 28-29; sien Bultmann 1971:350) ${ }^{35}$.

\subsection{Jesus, die wesenlike beliggaming van die opstanding en die lewe}

Die kruis is die kulminerende situasie waar die kontras tussen lewe en dood op ' $n$ intense wyse voorop staan (Van der Watt 2000a). Binne die kontrasdenke van die evangelie word God uitgebeeld as die God van lewe (vgl 6:57) en die duiwel as die vader en oorsprong van die leuen $(8: 44)$ wat bekend staan vir moord en verwoesting

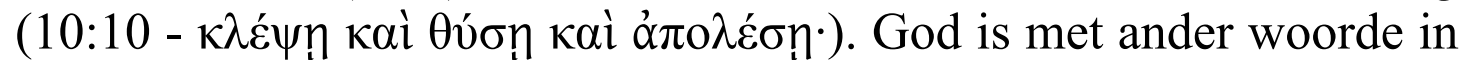

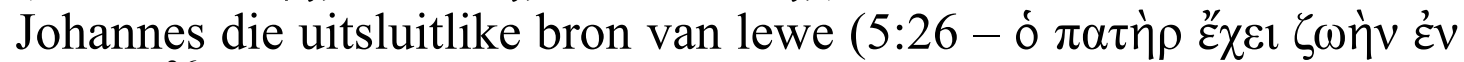
$\dot{\varepsilon} \alpha v \tau \tilde{\omega})^{36}$. Die wat lewe het kon dit dus alleen van die Vader ontvang het $(6: 51-58 ; 5: 19-21)$. Net so het Jesus ook hierdie lewe inherent in

33 Gnilka (1983:113) merk op dat "Jesus gemeinschaft is Gottesgemeinschaft, in Jesus wirkt und redet Gott, Umgang mit Jesus is Gottesschau! Er ist mit dem Vater völlig geeint, wie die Immanenzformeln (ich in ihm - er in mir) sagen". Die Immanenz word volgens Van der Watt (2000a: ad $l o c)$ tussen die Vader en die Seun word op verskillende maniere in die Evangelie uitgedruk: Die Vader en die Seun is een

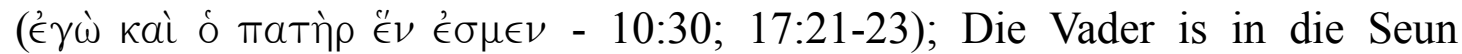

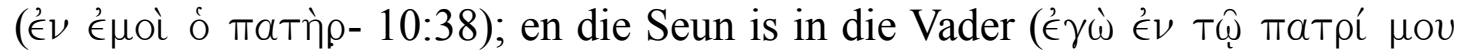
- 14:20). Sien Scholtissek (2000) vir die Immanenz uitsprake in die Johannese geskrifte.

34 Kysar (1986:199).

35 Lincoln $(2005: 266)$.

36 Gnilka (1989:130). 
Homself, en volgens Moloney (1998:222) het Hy die vermoë om dit te kan uitdeel van die lewende Vader self ontvang $(6: 57 ; 5: 26)$. Volgens Wengst (2000:197-198) koppel Jesus sy lewe-gewende vermoë aan die Vader as hy opmerk dat hy net soos sy Vader die dooies kan opwek en lewe kan gee $(5: 21)$ en oordeel, iets wat volgens die Jode alleenlik aan God toegesê kan word. Lincoln (2005:203) beklemtoon die feit dat die wat dit glo alreeds vanuit 'n bestaanstoestand van dood oorbeweeg het in 'n bestaanstoestand van lewe $(5: 24)^{37}$.

\section{Ekskursie: Jesus lê sy lewe neer met die doel om dit weer op te neem}

In 10:17-18 in die konteks van Jesus as die Goeie $\operatorname{Herder}^{38}$, kry ons volgens Van der Watt (2000a:ad loc) 'n geweldige belangrike teologiese blik op die onlosmaaklike verband tussen die kruis en die opstanding in die konteks van die Johannes teks self. In hierdie gedeelte verduidelik Jesus dat die Vader Hom liefhet aangesien Hy bereid is om sy lewe neer te lê (Maier 1984:455), net om dit weer op te neem (Moloney 1998:305). Hiermee word in die teks van Johannes self geillustreer dat die "Tod und Auferstehung Jesu unlöslich zusammengehören" (Schnackenburg 1971:379) en dat "Beide Gedanken sind unlöslich miteinander verbunden und dialektisch aufeinander bezogen"

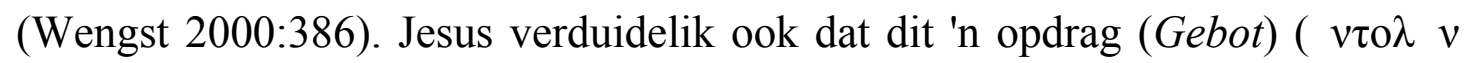
10:18) van die Vader is wat Hy uitvoer (Schnelle 1998:180; Wengst 2000:386).

Die vraag is dus of Jesus Homself opwek en of die Vader die Seun opwek (sien Morris 1995:181). Volgens Johannes is Jesus self direk aktief betrokke in sy opstanding (vgl Haenchen 1984:49) en neem niemand sy lewe

37 Schnelle (1998:107) merk op: "Im Hören des Wortes und im Glauben an den von Gott gesandten Sohn vollzieht sich der Schritt vom Tod zum Leben, ist das Heilsgut des ewigen Lebens bereits gegenwärtig. Der Glaubene kommt deshalb nicht in das Gericht, den er hat schon längst teil an der in Jesus Christus erschienenen Lebensmacht Gottes. Glaube und Heil fallen ebenso zusammen wie Unglauben und Gericht".

38 Moloney (1998:301) wys daarop dat daar in die Joodse tradisie 'n baie sterk Bybelse tradisie bestaan het ten opsigte van verwysings na herderskap. In die $\mathrm{Ou}$ Testament word daar verskeie kere gereflekteer oor slegte leiers wie se leierskap vergelyk word met slegte herders wat hulle skape aan die wolwe oorlaat (vgl Jer 23:1-8; Eseg 34, 22:27; Sef 3:3; Sag 10:2-3, 11:4-17). Hierdie tema word ook in buite-Bybelse bronne in ' $\mathrm{n}$ pre-Christelike konteks gevind (vgl 1Henog 89:12-27, 42-22, 59-70, 74-76; 90:22-25). In die Ou Testament word God ook gereeld as Herder uitgebeeld wat die verstrooide volk bymekaar maak (Jer 31:10; 13:17; 23:3; Jes 40:11; 49:9-10). 
van hom af weg nie (vgl 10:18; Maier 1984:455; Kysar 1986:121; Wengst 2000:385; Moloney 1998:496; Schnelle 1998:180). Volgens 10:17-18 lê Jesus sy lewe neer met die doel (ǐv $\alpha$ ) om dit weer op te neem. Die ǐv $\alpha$ rá $\lambda_{\mathfrak{l}} v$ konstruksie dui daarop dat die dood van Jesus die doel gehad het om uiteindelik uit te loop op die opstanding. Vir die gang van die huidige argument is hierdie 'n sentrale inhoudelike tekstuele bewys dat die skrywer van Johannes nie net die dood en opstanding onlosmaaklik aan mekaar verbind nie (Schnackenburg 1971:379), maar dat die kruis se uiteindelike doel gemik was daarop om te kulmineer in die opstanding. Die fokus of uitkoms van die kruis is dus bedoel

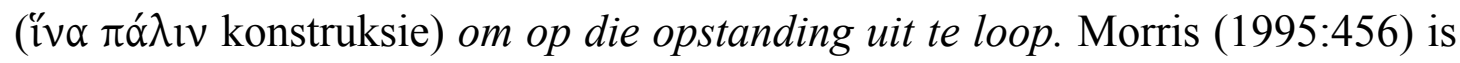
dus korrek as hy opmerk: "Christ dies in order that he may rise again. The death is not defeat but victory. It is inseparable from the resurrection" (vgl Wengst 2000:386; Kysar 1986:298) ${ }^{39}$. Jesus is dus aktief betrokke in sy eie opstanding (Haenchen 1984:49). Die feit dat Hy liggaamlik dood is maar steeds kan handel bewys die feit dat Hy die wesenlike beliggaming van lewe in oorvloed is en inderdaad die opstanding en die lewe is (11:25) omdat God lewe-skeppende mag aan die Seun oorgedra (5:26) het (vgl Maier 1984:221). Alhoewel Jesus fisies sterf het Hy steeds die kwalitatiewe goddelike lewe inherent in Homself $(1: 4 ; 5: 26)$ (Kysar 1986:30) Die fisiese dood beïnvloed dus nie die lewe nie slegs as die tipe lewe kwalitatief superieur is bo die fisiese lewe wat vergaan het. Schnelle (1998:34) merk in hierdie verband (vgl 1:4) op: "Im Logos ist das Leben gegenwärtig, er ist der Ort des Lebens, und nur das Licht des Logos erhellt das Leben der Menschen".

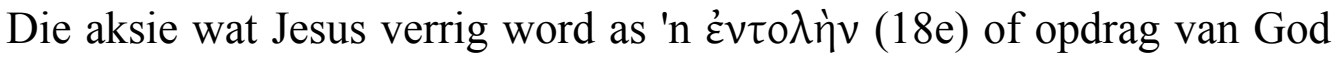
beskou en is gemotiveer deur liefde (17a - sien ook 3:35; vgl Maier 1984:454). Van der Watt (2000a:ad loc) merk op: "Even though Jesus is actively involved

39 Kysar (1986:298) beskou die opstanding binne die reddingsplan van God ( $3: 14 ; 12: 34)$ wat die lewe aan die wêreld kom bring het. Volgens Van der Watt (2000:ad loc) moet hierdie teologiese motief verstaan word in die lig van die Ou-Testamentiese konsep dat God die God van lewe is. Daar waar lewe te vinde is, daar is God ook teenwoordig en betrokke. Die dood impliseer die verlies en afwesigheid van lewe. Daarom word die dood geassosieer met daardie sfeer waar God nie teenwoordig is nie. Wanneer Jesus dan self die dood binnegaan bewys Hy dat Hy inderdaad die Lewe is en dat Hy outoriteit oor die dood het. Human (2007:16) stem hiermee saam en merk op: “Dood' was nie net 'n lewelose liggaam nie. Dit was eweneens die afwesigheid van lewe of God. Siekte, bedreiging van vyande of die gevolge van verkeerde dade was doodsbelewenisse (Ps 44:23; 88). Om weg van Jerusalem of die tempel te wees, was ervaring van die dood (Ps 137); daarom was Israel se terugkeer uit ballingskap herlewing uit die dood (Eseg 37)". 
in his own resurrection, He still does it with and under the charge of his Father. If John, therefore, says that Jesus lays down his life and takes it up again, He does so on the basis of his intimate relationship to the Father" (Dietzfelbinger 2001:312).

Die Vader se betrokkenheid by die Seun in die opstanding word verder

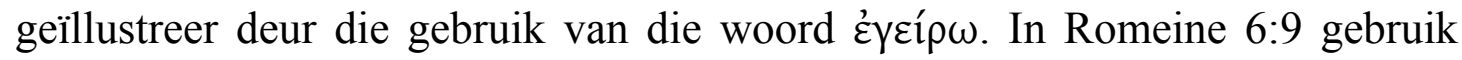

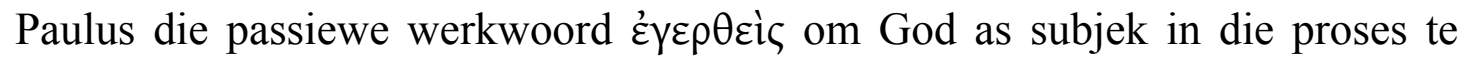
betrek (Van der Watt 2000a:ad loc). In Johannes 2:22 gebruik Johannes ook die

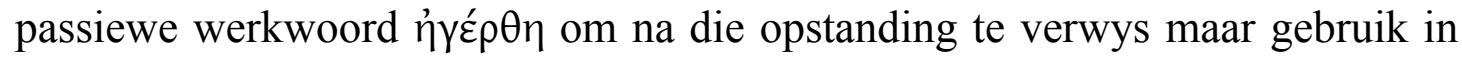
die onmiddellike konteks $(2: 19,20)$ die aktiewe vorm van die werkwoord. Die passiewe werkwoord in 2:22 wil moontlik aandui dat die lewe en opstanding sy oorsprong in God as primêre bron van lewe het soos dit in 10:17-18 voorkom (Dietzfelbinger 2001:312-313). Tog word die mag oor lewe en dood aan Jesus gegee (5:21) wat Homself sal opwek. Daarom is Van der Watt (2000a:ad loc) korrek as hy argumenteer dat die Vader op 'n intieme wyse by die Seun in die opwekking betrokke is maar dat die Seun wel die beliggaming van lewe is: "Jesus is not just the mediatory agent of life, but he is life himself (11:25)." Wengst (2001:26) merk op: "Zum anderen kann der Evangelist Jesus, der ebenfalls gestorben ist, doch nur deshalb sagen lassen: 'Ich bin die Auferstehung und das Leben', weil von ihm bezeugt worden ist, dass Gott ihm von den Toten auferweckt hat".

In en deur die opstanding per se word dit duidelik dat Jesus die Seun van God is. Tomas se belydenis word die hermeneutiese sleutel waarmee die res van die evangelie geïnterpreteer word (20:24-25,28). Jesus was dood en nou lewe Hy weer wat net illustreer dat Hy inderdaad lewe in Homself het (Maier 1984.1:21), iets wat net aan God toegeskryf kan word (Wilckens 1998:168) ${ }^{40}$.

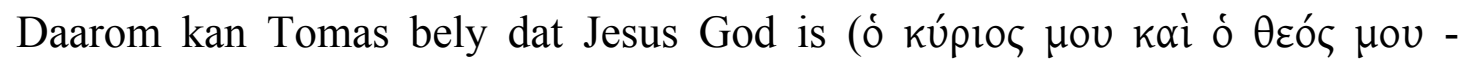
20:28). Van der Watt (2000a:ad loc) som dit akkuraat op: "This confession of Thomas represents the pivotal point in the Gospel. It formulates the identity of Jesus, the Agent of God who died on the cross, but now lives and therefore may be identified as Lord and God. The cross events not only illustrate that the living God, the Lord of life, is with Jesus, but that Jesus Himself is involved in his own resurrection and should therefore be confessed as Lord and God himself'.

40 Wilckens (1998:168) is korrek as hy opmerk: "Wie der Vater die Vollmacht der Totenauferweckung innehat $(16,3)$, hat sie auch der Sohn $(5,21)$, nicht nur zue Auferweckung der Seinen, sondern auch $\mathrm{zu}$ zeiner eigenen Auferstehung". 


\section{KAN DIE KRUISGEBEURE ${ }^{41}$ BINNE GENESINGS- TERME VERSTAAN WORD?}

In die hantering van die begrip siekte word daar in hierdie artikel bepleit vir ' $n$ breë verstaan daarvan wat wyer as die Westerse Biomediese paradigma se "disease" verstaan word in die sin van die meer inklusiewe term "illness". Die begrip "illness" maak ruimte vir "ongesteldheid" wat die kulturele gebrokenheid in die antieke konteks verdiskonteer. Nou verwant aan die begrip "illness" staan die begrip gebrokenheid, wat teenoor heelheid in 'n tempel georiënteerde Joodse simboliese universum staan. Siekte of "illness" (ongesteldheid) tas heelheid aan en resulteer in ' $n$ mindere of meerdere mate in gebrokenheid. Genesing ${ }^{42}$ word dus in hierdie

41 Met kruisgebeure word die kruisdood en opstanding van Jesus bedoel.

42 Saam met Wilkinson (1998:5) word daar ten gunste van ' $n$ breër verstaan van die begrippe siekte en genesing of dan "healing" en "illness" geargumenteer: "Another aspect of our use of the word healing in this book is that we include three categories of the restoration to normality within this scope. These are healing of the body, the casting out of demons and the raising of the dead." In die artikel word die woorde "genesing", "restourasie" en soms ook "herstel"gebruik om die genesingshandelinge van Jesus te beskryf. Die veronderstelling is dat Jesus tydens die transformasionele interaksie die gebrokenheid (illness wat soms ook disease insluit) van die individu genees deur hom te "cure" van sy "disease" maar hom ook te "restoureer" van sy "gebrokenheid" (illness). Die moderne leser is nie net histories nie, maar ook kultureel duisende jare verwyder van die antieke konteks en sy lesers met die gevolg dat die genesingsverhale in die Bybel dikwels deur die etnosentriese bril van die Westerse biomediese model gelees word. In die proses maak die moderne leser hom of haarself dikwels skuldig aan etnosentriese wanvertolkings (Pilch 2000:40). Indien daar in Afrikaans oor Jesus se genesingshandelinge besin word, word die volgende woorde vir die doel aangewend: *Daar word van die voorveronderstelling beweeg dat daar een of ander "sieke" is wat 'n "siekte" of "ongesteldheid" het; *Jesus tree dan as "geneesheer" op wat die sieke se siekte of ongesteldheid "genees" of "herstel". Wanneer daar oor die konsep "siekte" gepraat word, word daar meer as dikwels vanuit ' $\mathrm{n}$ Westerse biomediese denkraamwerk gedink. Daar word myns insiens selde aan die volle implikasies van siekte en die sosiaalreligieuse implikasies daarvan gedink. Die gevolg hiervan is dat daar dikwels op reduksionistiese wyse oor Jesus se genesingshandelinge in kulturele perspektief gedink word, of dat die volle implikasies van die genesingshandelinge nie ten volle ontwikkel word nie. "Sickness" word binne die Medies-Antropologiese dissipline as 'n sambreelterm aangewend om die menslike belewenis van "disease" aan die een kant, en "illness" aan die ander 
konteks as restourasie van gebrokenheid gesien - nie net op fisiese of biomediese vlak nie, maar ook op sosiaal-religieuse vlak. Hierdie raamwerk verteenwoordig 'n poging om nader aan die antieke mediterreense verwysingsraamwerk te kom. Vanuit ' $n$ postmoderne Westerse georiënteerde wêreldbeeld is dit vreemd om daaraan te dink dat wanneer daar oor "siekte" of "gebrokenheid" en "genesing" en "restourasie" besin word, dit moontlik ook religieuse genesing kan insluit. Die rede daarvoor is dat die Westerse georiënteerde wêreldbeeld se verstaan van siekte en genesing 'n produk is van die biomediese paradigma, wat bepaalde moderne wetenskaplike assosiatiewe konseptuele raamwerke insluit. In die antieke Mediterreense denke is daar egter anders oor siekte en genesing gedink, en die terme is dikwels gebruik om sosiaal-religieuse gebrokenheid of restourasie mee te beskryf. Green en andere (1992:81) stem hiermee saam en merk op:

The Gospels, like elsewhere in biblical literature, frequently use the words blindness, deafness, eye and ear in a figurative sense, conveying more than the activity of the body's sense organs. God is made known through words and deeds. To see and hear God's revelation fully requires not only physical sensation but spiritual sensitivity. It requires a personal response of understanding and commitment. Therefore, blindness and deafness can describe the inability to comprehend the spiritual truth inherent within material sights or words. This condition of hardness of heart may be due to religious or moral impairment, or due to God's intention.

kant, uit te druk. Pilch (1991:191) merk op: "Think of 'sickness' as genus, and 'disease' and 'illness' as 'species'." "Curing”'(Genesing) is die geantisipeerde uitkoms relatief tot "disease" (siekte) wat verstaan kan word as die neem van effektiewe beheer oor biologiese en psigologiese prosesse (Pilch 2000:25). "Healing" (Herstel) is ter sprake by "illness", wat die formulering van persoonlike en sosiale sin en betekenis in die lig van "illness" en die gevolglike lewensprobleme wat daaruit spruit insluit (sien Wilkinson 1998:1-6). Bogenoemde onderskeiding wat die mediese antropologie maak, is van kardinale belang vir hierdie tese. Wanneer daar dus in hierdie artikel oor siekte gepraat word, word daar nie in die eerste plek slegs vanuit 'n Westerse paradigma van disease gedink nie, maar vanuit 'n eerste eeuse tempelgeoriënteerde Joodse perspektief van illness, wat geestelike ongesteldheid en geestelike genesing insluit. 
Salvation is frequently associated with sight in Jewish and Christian literature (Ex 14:13; 2 Chron 20:17; Ps $50: 23 ; 91: 16 ; 119: 123$; Is $40: 5 ; 42: 16-17 ; 59: 11 ; 1 Q S$ 11:2-3; CD 20:34; T. Gad. 5:7; 2 Clem 1:6-7; 9:2). The formula of the frequently quoted Shema emphasizes the equally important role of hearing in revelation: "Hear, $\mathrm{O}$ Israel, the Lord our God, the Lord is one" (Deut 6:4). It is a call to discern and obey the will of God. In contrast to God who both "sees" and "hears" (Ex 2:24; 3:7, 9; 12:13; Deut 5:28; Is 37:17; Zech 7:11-13), idols are "blind" and "deaf" (Deut 4:28), as are those who worship them (Ps 115:5-6). The OT prophets chasten the Hebrew people for having eyes and ears, and yet not seeing or hearing (Is 6:9-10; 43:8; Jer 5:21; Ezek 12:2). Responsibility for such spiritual blindness and deafness is sometimes said to be borne by God (Deut 29:4; Is 6:9-10) but, on the other hand, can be traced to the person's own obduracy. Yet God can overcome this hardness of heart (Is 29:18; 35:4$5 ; 42: 6-7,16 ; 61: 1)$.

Johannes se genesingsverhale is tekens $(\sigma \eta \mu \varepsilon i \tilde{\alpha})$ wat ' $n$ bepaalde punt wil illustreer, naamlik dat Jesus die bron van kwalitatiewe (ewige) lewe is en lewensmoontlikhede binne die familie van God skenk. In hierdie sin wys die genesingshandelinge as $\sigma \eta \mu \varepsilon i \tilde{\alpha}$ heen na wie Jesus werklik is, naamlik dat Hy die gestuurde Seun van God, die bron van lewe is en dat Hy gekom het om die wêreld te red van 'n doodsbestaan (vgl 3:16; 5:24) en gelowiges in die dampkring van die familie van God in te trek $(1: 12)$. Anders gestel, die sending van die Seun het ten doel om mense tot geloof te bring in Jesus en hulle gebroke verhouding met God te herstel $(3: 16 ; 20: 30-31)$ en hulle ewige lewensmoontlikhede te skenk. Die herskepping van lewensmoontlikhede binne die familie van God kan ook as genesing of restourasie beskou word. Die wat glo, is in Johannes diegene wat van geestelike blindheid genees is (vgl 9:41; 12:40), die koninkryk van God kan sien (vgl 3:3) en die reg ontvang het om kinders van God genoem te kan word $(1: 12)$. In hierdie sin word die sending van die Seun met genesing verbind in die sin dat geloof die resultaat van bekering is en bekering in Johannes die genesing van geestelike blindheid behels (sien $3: 3 ; 9: 41 ; 12: 40$ ). 


\subsection{Realisering van post opstandings- lewensmoontlikhede}

\subsubsection{Die eskatologiese era van die Gees}

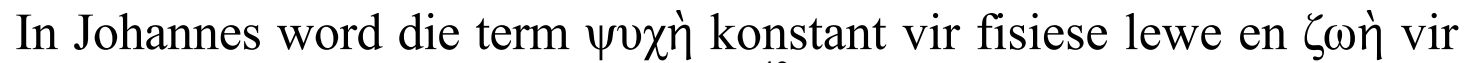
ewige lewe gebruik. In 10:17-18 $8^{43}$ verduidelik Jesus dat Hy sy

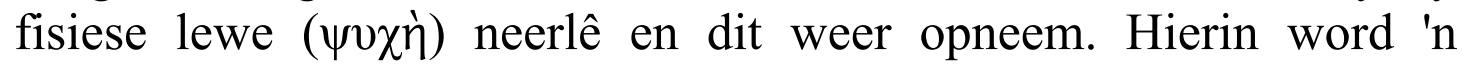

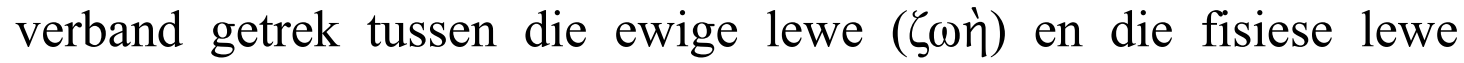

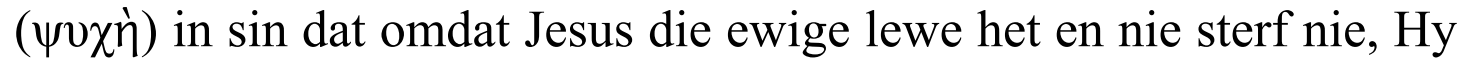
sy fisiese lewe kan aflê en weer kan opneem. Anders gestel: Jesus het of besit die ewige lewe, en daarom kan Hy die fisiese faset daarvan beheer aangesien die aard van die ewige lewe wat Hy besit kwalitatief gesproke nie sy fisiese lewe kan wegneem nie. Toe Jesus Homself uit die dood opwek en daarmee Homself genees of restoureer tot lewe het die eskatologiese era van die Gees aangebreek $^{44}$ (vgl 3:34-35; 7:37-39; 20:22). Hierdie gawe van die Gees moet natuurlik in die lig van die Ou-Testamentiese verwagting van die lewebrengende teenwoordigheid van die Gees in die eskatologiese eindtyd gesien word, veral teen die agtergrond van die Esegiël-uitsprake (vgl Van der Watt 2000a: ad loc) ${ }^{45}$. In die gawe van die Gees deur Jesus is dit God self wat sy profetiese beloftes waar maak.

Nadat Jesus uit die dood uit opgestaan het verskyn hy aan sy

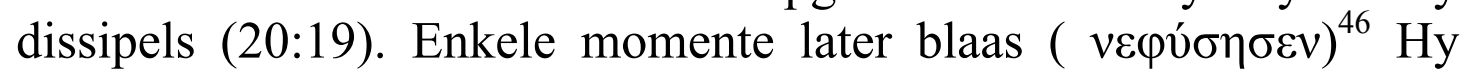

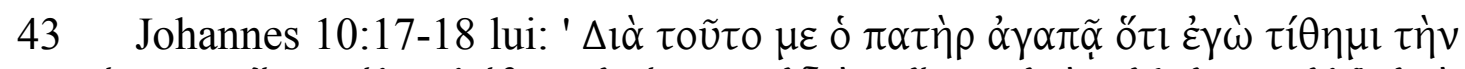

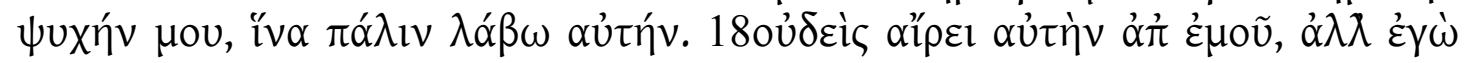

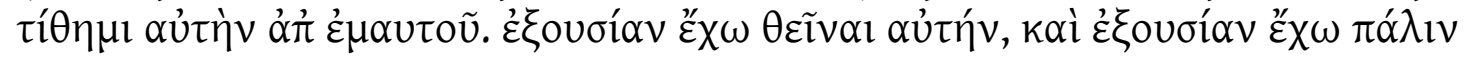

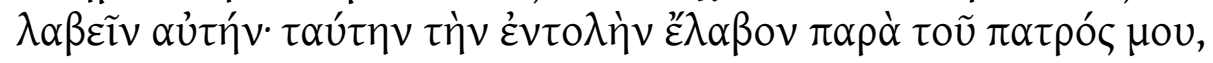

44 In 7:39 word die vloei van strome van water met die eskatologiese teenwoordigheid van die Gees verbind wat deur die passie van Jesus 'n realiteit geword het.

45 Hier kan byvoorbeeld aan Eseg 11:19; 18:31-32; 36:26-27; $37: 1$ gedink word.

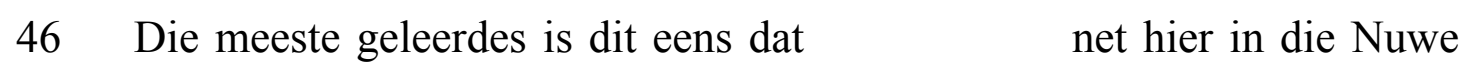
Testament voorkom. Dit het heel waarskynlik verwysings na Genesis 2:7 waar

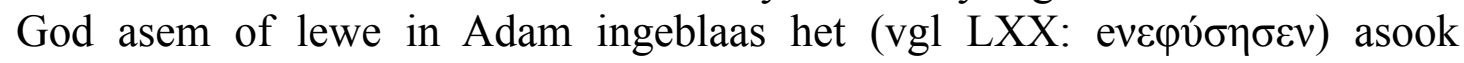

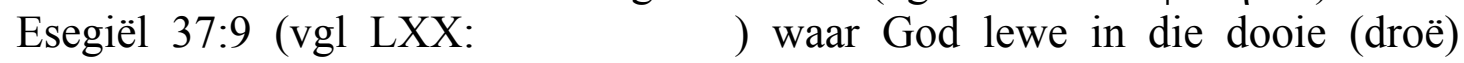
beendere inblaas. Lindars (1972:611) is korrek as hy opmerk: "With this symbolic action Jesus fulfills the expectation of 1.33 and the promise of the paraclete (cf also 7.39)... This suggests that John sees the constitution of the Church after the Resurrection as a kind of new creation". Die tema van nuwe lewe en die herskepping of realisering van verlore lewensmoontlikhede kom 
oor die dissipels en hulle ontvang die Heilige Gees (20:22). Daarmee word God se teenwoordigheid in die Jesusgebeure onmiskenbaar bevestig en dui dit op die gesagsoordrag van Jesus as Hy sy dissipels stuur (20:21-23) en aan hulle die mag gee binne die heilsplan van God (Van der Watt 2000a:ad loc). Daarmee breek die eskatologiese era van die Gees aan ${ }^{47}$, sien die ongelowige Tomas die merke aan sy hande en verklaar dat die opgestane Jesus Here en God is (20:28). In die lig van die opstanding word die kruisgebeure geherinterpreteer, gerepresenteer in die dampkring van $\delta$ ó $\xi \alpha$, sodat selfs die ongelowige Tomas nie anders kan as om die kruis as Goddelike magsvertoon en verheerliking te beskou nie.

Dit is dus eers deur die perspektief van die kruis dat die aardse optrede van Jesus in sy geheel, sowel as die volle betekenis daarvan, werklik duidelik na vore tree. Hierdie perspektief word veral duidelik teen die agtergrond van die feit dat die dissipels van Jesus self nie alles tydens sy lewe en werk verstaan het nie $(2: 22 ; 12: 16$; $13: 7 ; 20: 9)$. Eers retrospektief in die lig van die opstanding en die uitstorting van die Gees $(2: 22 ; 20: 22)$ kon die dissipels die kruis as $\delta o ́ \xi \alpha$ sien (vgl 2:22) en "kon die dissipels deur pneumatiese verligting die vervlegting van die profetiese tradisies en die Jesusgebeure na waarde skat"(Van der Watt 2000a:ad loc).

Jesus se opstanding is nie in die eerste plek alleen net op sy eie genesing en restourasie gemik nie, net soos sy genesingshandelinge op aarde altyd in diens gestaan het van God se Universele Goddelike Narratief. Kysar (1986:30) merk op dat in 1:4 die Woord gedefinieer word as goddelike skeppings-agent deur wie God se kreatiewe

hier sterk op die voorgrond. Nie net restoureer Jesus sy eie gebrokenheid deur nuwe lewe te skep nie, maar "blaas" of skenk ook dan hierdie lewe en lewensmoontlikhede aan die dissipels en uiteindelik die mensdom.

47 Van der Watt (2000a:ad loc) merk op: "So word die teenwoordigheid van God onder sy volk met die opstanding van Jesus ingrypend verander. Nie meer die tempel in Jerusalem of selfs op Gerasim sal daar in aanbidding voor God neergebuig word nie (4:21-24), maar in die pneumatologiese teenwoordigheid van die opgestane Here sal toegang tot God verkry word $(2: 18-22 ; 14: 18-20)$. Daarom vorm die gawe van die Gees ook 'n hoogtepunt in die passieverhaal self. Met die aankondiging van die eskatologiese vrede blaas Jesus oor die dissipels en gee aan (doop met) hulle die Heilige Gees (20:22). Daarmee is God se teenwoordigheid in die Jesusgebeure onmiskenbaar bevestig. Dit spreek ook uit die gesagsoordrag van Jesus as Hy sy dissipels stuur en aan hulle die mag gee binne die heilsplan van God (20:21-23)". 
herskepping voortgebou word in so 'n mate dat alle eksistensie afhanklik is van die Woord se herskeppingsvermoë. Die Woord is dus die bron van lewe $(1: 4 ; 11: 25)$. Die Johannese konsepte lewe en lig, wys vir Kysar heen na 'n verhoudingsrealiteit. In 1:5 word die dualisme van die evangelie geskets waarvolgens die Woord in konflik met die duisternis staan. Vir Kysar (1986:30) verteenwoordig die duisternis distorsie van die skepping, chaos van ongeloof en vervreemding van God. In die konteks van hierdie kosmiese konflik kon die duisternis die Woord as lig en lewe nie oorweldig

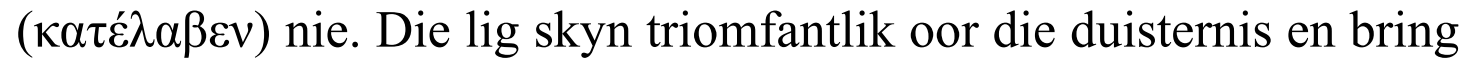
lewe en verhoudings-moontlikhede aan die wêreld (6:33).

Jesus se opstanding staan uiteindelik in diens van God se groot verhaal van Genesing en restourasie van die gebroke verhouding (1:10-11) tussen Hom en die wêreld (3:14-16; 20:30-31). Jesus word genees en sy gebrokenheid word deur lewe-skeppende energie gerestoureer, sodat 'n gebroke wêreld uiteindelik gered kan word en kwalitatiewe lewensmoontlikhede binne God se familie kan ontvang (1:12). In die konteks van 3:14-15 word dit duidelik gestel dat die verhoogde Seun van God die wêreld in liefde (3:16) na hom toe sal trek (12:32) sodat hulle lewe kan ontvang $(3: 14-16 ; 20: 30-31)$ en hulle die openbaring kan raaksien van wie Hy werklik is $(8: 28)$. As lig vir die wêreld stel Jesus die gelowige mensdom in staat om nie in die bestaanstoestand van duisternis vasgevang te bly nie en daarin te vertoef nie (12:46) maar dat gelowiges nou reeds kan oorbeweeg van 'n bestaanstoestand van dood na ' $n$ bestaanstoestand van lewe $(5: 24)$. Alhoewel Johannes in sy evangelie nie die woord versoening (i $\lambda \alpha \sigma \mu$ ó $\varsigma$ - vgl 1 Joh 2:22) gebruik nie, bespeur ons tog die spore daarvan in sy teologie. God "versoen" die wêreld wat in vyandskap met Hom leef (8:44) met Homself deur sy Seun te stuur sodat die wat in Hom glo nie verlore sal gaan nie maar die ewige lewe kan ontvang (3:16) en kinders van God genoem kan word (1:12). So word die opstanding die Groot Genesingshandeling in die evangelie volgens Johannes. God het dus sy Seun gestuur $(3: 16)$ om rekonsiliasie tussen Hom en die wêreld te bewerkstellig deur die voorheen gebroke verhouding te herstel of te genees (vgl Joh 9:40$41 ; 12: 41)$, en in die proses kwalitatiewe lewensmoontlikhede binne die familie van God te skep (1:12).

Volgens die Johannesevangelie is die (ongelowige) wêreld vasgevang in ' $\mathrm{n}$ doodsbestaan (vgl 5:24). Die simboliese universum binne die Evangelie maak dit duidelik dat daar ' $n$ dualistiese kontras 
bestaan met geen grysgebied nie (Maier 1984:219). Daar is ' $n$ duidelike kontras regdeur die evangelie te bespeur: lewe staan teenoor dood, lig teenoor duisternis, waarheid teenoor leuen, liefde teenoor haat, goed teenoor sleg, ensovoorts ${ }^{48}$. Die Vader het die Seun gestuur om die lig, lewe en waarheid na 'n wêreld vol duisternis, dood en leuens te bring (Schnelle 1998:107-108).

Waar Jesus is, word goddelike kwaliteite soos lewe en waarheid aangetref $^{49} \quad(1: 4 ;$ Gnilka 1983:14; Schnackenburg 1990:242-244) ${ }^{50}$. In 5:20 sê Jesus dat God hom nog groter werke as

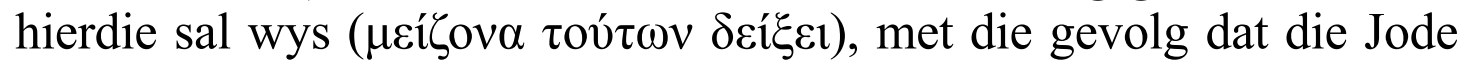
verwonderd $(\theta \alpha v \mu \alpha ́ \zeta \eta \tau \varepsilon)$ sal staan (Ridderbos 1997:95; BeasleyMurray 1987:76). Dit verwys natuurlik na die gee van lewe en opwekking van mense uit die dood: In 5:21 lees ons: Soos die Vader

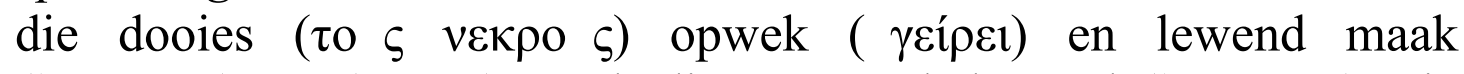

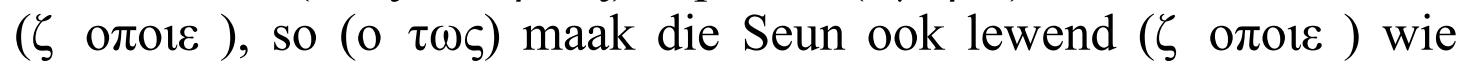
Hy wil $(\theta \varepsilon \dot{\varepsilon} \lambda \varepsilon)$. Die gee van lewe is een van die vernaamste take wat God aan Jesus gegee het $(3: 16 ; 20: 30-31)^{51}$. Aan die ander kant van

48 Schnelle (1998:106).

49 God is die primêre Bron van Lewe, Lig en Waarheid (6:57) en die lokus van kontrole in terme van eer en oneer lê by God. Eer in Johannes word dus bepaal relatief tot ' $n$ bepaalde persoon of groep se verhouding met God en sy Seun Jesus $(5: 23 ; 8: 50 ; 12: 26)$. Juis om hierdie rede onderrig en bemagtig die Vader die Seun soos 'n antieke vader sy eie seun onderrig het. Soos 'n koning sy gesag oorgedra het aan die een wat hy gestuur het, so dra die Vader gesag oor aan die Seun (Van der Watt 2000a en 2000b; sien Dietzfelbinger 2001:168). Daarom kan die Seun die Lewe gee aan wie Hy wil en kan Hy oordeel (5:21; Maier 1984:1.215; Wilckens 1998:117) in "königlicher Vollmacht" (Dietzfelbinger 2001:168; vgl 18:37; 19:17-22). Schnelle (1998:107) merk op: "Glaube und Heil fallen ebenso zusammen wie Unglauben und Gericht".

50 Volgens Johannes word die goddelike kwaliteite aan Jesus as persoon verbind. Van der Watt (2000a:150) meen dat Jesus die nuwe tempel is, die plek waar daar aanbid moet word, by Hom is reinheid te vinde. Die heilswerklikheid word dus geheel en al verchristologiseer in die Evangelie volgens Johannes.

51 Witherington (1995:142) sê: "Part of what the Father has authorized and empowered the Son to do is to give life, to be able to raise the dead - a power early Jews believed was solely in the hands of God". Sien ook sy bespreking van Jesus as agent wat deur die Vader gestuur is (Witherington 1995:140-142). Volgens Köstenberger (2004:87) verwys die "groter dinge" nie net na die gee van lewe nie, maar "will be seen in the ever-escalating series of 'signs' performed by Jesus ..." Myns insiens kulmineer die semeia van Jesus nie net in 
lewe gee, staan oordeel en dood (5:22), iets wat volgens die $\mathrm{Ou}$ Testamentiese denke die eksklusiewe prerogatief van God is (vgl Gen 18:25; sien Rig 11:27; Ps 2:2). In die lig hiervan sê Jesus in

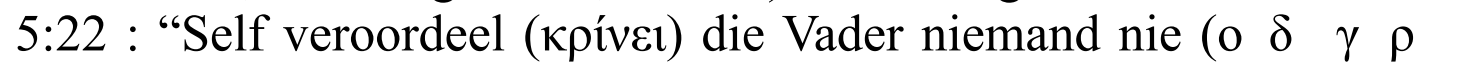

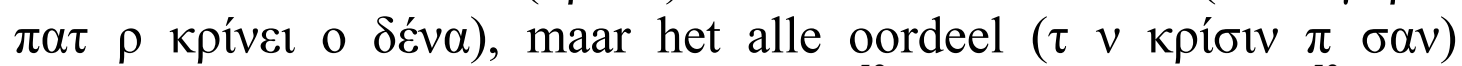

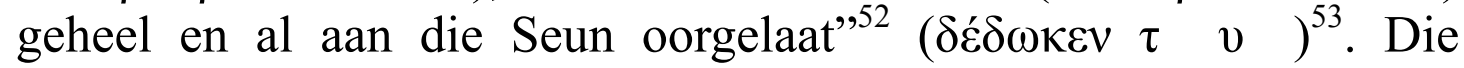
skeiding (3:19) kom egter duidelik tussen die gelowiges en die ongelowiges, die ewige lewe en die ewige dood (5:24), die kinders van die duiwel (8:44) en die kinders van God (vgl 1:12).

\subsection{Die krisis van die Universele Goddelike Narratief}

Alhoewel Jesus in ' $n$ ideale posisie van lewensmoontlikhede verkeer in die sin dat Hy in " $n$ nabye verhouding met God staan en eer in God se oë geniet, verkeer Hy in ' $n$ sekere sin in ' $n$ ongunstige posisie op aarde (vgl haat in $3: 20 ; 7: 7 ; 15: 18-19,23-24 ; 17: 14)$. Dit lei tot geweldige spanning in die evangelie volgens Johannes: "Das aber ist das Gericht, dass das Licht in die Welt gekommen ist und die Menschen die Finsternis mehr liebten als das Licht" (Maier 1984:126). Die realiteit van die saak is dat die Woord na die wêreld, sy eiendom, gekom het maar dat hulle Hom nie erken of aanvaar nie

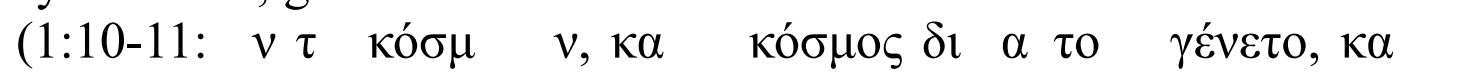

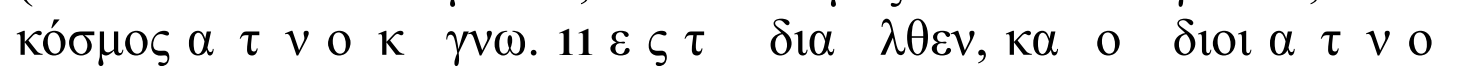
$\pi \alpha \rho \varepsilon ́ \lambda \alpha \beta o v)$. So eer die Joodse leiers nie vir Jesus nie, en weier hulle om sy status as gestuurde Seun van God te erken. Dit is dan juis die krisis wat homself voordoen in die evangelie in die breë. Jesus se liefdevolle optrede in navolging van sy Vader se agenda (3:16) word gemisinterpreteer en lei uiteindelik tot sy verwerping en dood.

Jesus se woorde en dade veroorsaak dat Hy in konflik kom met die Joodse leiers. In en deur sy optrede doen Hy die werke van die Vader en gee hy lewe en gevolglike lewensmoontlikhede aan mense

die kruisdood nie maar in die opstanding as die grootste teken van lewe en opwekking uit die dood.

52 Wilckens (1998:117) maak egter die volgende belangrike opmerking: "Die Übertragen 'des ganzen Gerichts' auf den Sohn bedeutet nicht, dass der Vater sich damit aus dem Gericht völlig herausgezogen habe und nun nur noch der Sohn der einzige Richter sei. In 12,47f, ist das Gegenteil zu lesen. Der Sinn der Aussage ist: Gottes Richten fällt mit Jesu Richten zusammen".

53 Ridderbos (1997:8) meen dat Jesus se intieme verbintenis met God direkte implikasies inhou ten opsigte van die mag oor lewe en oordeel as uitvloeisel van hierdie verhouding. 
(5:21). Die ironie is dat die Jode blind is en dat hulle nie kan sien wie Jesus werklik is nie (9:39-41) en "[I]n Blindheit verharrt (Schnelle 1998:174).

Die krisis van die Universele Goddelike Narratief, soos hier bo verduidelik, bestaan daaruit dat Jesus van die begin af by God was en betrokke was by die skepping (1:1). God het sy eiendom, dit wat Hy gemaak het oneindig lief, maar Sy eiendom ken Hom nie. In sommige gedeeltes word dit selfs met haat uitgedruk (vgl 17:14; 3:20; 7:7; 15:18, 19, 23, 24, 25). Die Krisis in die Universele Goddelike Narratief wentel juis rondom hierdie gebroke verhoudingsrealiteit. Die wêreld het die duisternis liewer as die lig (3:19). Daar bestaan ' $\mathrm{n}$ wesenlike gebroke verhouding tussen God en mens (Morris 1995:412). Die krisis bestaan verder in die feit dat die mensdom in 'n bestaanstoestand van dood (5:24), duisternis (12:35, 46) en leuen (8:44) vasgevang is en dat die duiwel hulle vader is (vgl

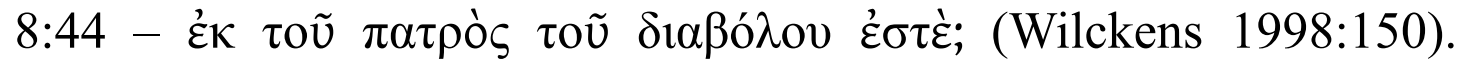
Daarom ken hulle Hom nie en verwerp hulle Hom (Ridderbos 1997:316; Wilckens 1998:150). Selfs al wek Hy dooies uit die dood uit op (Joh 11), bly hulle blind $(9: 40-41 ; 12: 40)$ en smee hulle 'n komplot om Hom dood te maak (11:45-57).

In en deur die opstanding toon Jesus aan dat ware lewe net by Hom te vinde is (11:25). Soos wat die Vader lewe in Homself het, so het Jesus ook die ware lewe in Homself (5:26). In en deur die opstanding het Jesus nie net die dood oorwin nie, maar ook aangedui dat Hy en die Vader een is en dat Hy die mag het om lewe te gee aan wie Hy wil (5:21). Deur die opstanding het hy aangetoon dat Hy inderdaad die gestuurde Seun van God is $(3: 17 ; 34 ; 4: 34 ; 5: 23,24$, $30,36,37,38 ; 6: 29,38,39,40,44,57 ; 7: 16,18,28,29,33 ; 8: 16,18$, $26,29,42,9: 4 ; 10: 36 ; 11: 42 ; 12: 44,45 ; 13: 16,20 ; 14: 24 ; 15: 21$; $16: 5 ; 17: 3,8,18,21,23,25 ; 20: 21)$. Die realiteit van die opstanding illustreer dat Hy nie net die mag het om lewe te gee nie, maar dat sy woorde waar was en dat Hy inderdaad die gestuurde Seun van God is wat lewe kom bring het (20:30-31). Deur die dood as finale marginaliserende realiteit te oorwin, oorwin Jesus alle marginaliserende realiteite denkbaar. As Jesus sy lewe weer opneem en die dood oorwin, genees of herstel Hy nie net sy eie gebrokenheid nie. Jesus verkry die mag om oor alle grense (of kaarte) van persone, plek, tyd en objekte heen totale genesing, restourasie en rekonsiliasie te bewerkstellig. Jesus is die Seun van God wat tot in alle ewigheid lewe kan skep en lewe in stand kan hou (14:1-3). In hierdie sin is die 
opstanding die bewys dat Jesus kan genees en dat Hy (ewige) lewe kan skep. Die opstanding is dus die kulminerende holistiese genesingshandeling van God deur sy Seun.

\subsubsection{Reoriëntasie}

Met die kruisdood van Jesus wil dit deur die menslike ö van ongeloof voorkom of die ganse sin en betekenis van Jesus se lewe in impotensie stol $^{54}$. Die sleutel tot die "regte" manier van kyk lê volgens Johannes se Jesus in die realiteit van die wedergeboorte (vgl 3:5 en 3:7): "Wer nicht von oben her neu geboren wird, kann das Reich Gottes nicht sehen" (Wengst 2000:120) en dit gaan uiteindelik oor die "Werden eines neuen Menschen, der durch seine Geburt eine neue Herkunft erhält" (Wengst 2000:121). Dan alleenlik sal die familielede van God wat in geloof opkyk na die kruis dit kan sien as ' $n$ bron van genesing en lewe soos destyds in die krisis-tyd (disoriëntasie) in die woestyn toe Moses die slang hoog op 'n paal gesit het (vgl Num 21:4-9) en die slagoffers genesing en lewe ontvang het (3:14-15; Gnilka 1983:28-29).

Met stylvolheid en kunstigheid plaas Johannes die dood van Jesus in die konteks van $\delta$ ó $\xi \alpha$. of verheerliking in die lig van die opstanding (Gnilka 1983:29; Wengst 2000:1.132-133). Hiermee slaag hy daarin om ' $n$ interessante wending te skep en die leser te verras met nuwe insigte. Uit die situasie van disoriëntasie word die profane werklikheid getransformeer as Jesus uit die dood uit opstaan tot lewe. So word Jesus se dood finaal as $\delta$ ó $\xi \alpha$ gestempel en is die dood van Jesus nie ' $n$ profane mislukking nie maar ' $n$ sakrale eksistensieel-transformatiewe, simboliese, oorwinnings-werklikheid (Schnackenburg 1965:409) ${ }^{55}$. Die opstandingsmetafoor word 'n

54 Barrett (1978:206) argumenteer ook dat bonatuurlike geboorte 'n belangrike rol speel in Johannes en dat dit te doen met die vernuwing van die totale mens en dat "The experience cannot be communicated $\mathrm{n}$ rational terms ..." (Barrett 1978:207).

55 Daar kan met Schnackenburg (1968:409) saamgestem word dat Johannes se aanbieding van die kruisdood van Jesus nie as vernedering (Ärgernis) beskou word nie, maar myns insiens kan Johannes die kruis as Verherrlichung beskou aangesien hy vanuit die realiteit van die opstanding na die kruis kyk. Hier bo is die teologiese eenheid van die kruis en opstanding van Jesus aangetoon (vgl 2:18-22; en veral 10:17-18) waar ons gesien het dat God die Seun liefhet omdat Hy die opdrag uitvoer - die opdrag wat bestaan in die neerlê en die opneem van sy lewe. Die opstanding is myns insiens nie net die 
simboliese bron van hoop wat getuig van die bevrydende waarheid van Jesus se vermoë om lewe uit dood te skep omdat Hy self die bron van lewe is $(1: 4 ; 11: 25$; sien Barrett 1978:395-396; Carson 1991:412; Gnilka 1983:14; Schnelle 1998:34).

Bogenoemde omhels dit wat Brueggemann as die tipiese "impossibility" - struktuur beskryf waarvolgens die "conventional definitions of reality do not contain or define what God will yet do in Israel" (1995:xvii). In Johannes breek Jesus telkens deur die konvensionele strukture van die dag wat lewensmoontlikhede inhibeer deur aan te toon dat Hy inderdaad die ware bron van kwalitatiewe lewe (en gevolglike lewensmoontlikhede) is (Barrett 1978:395-396; Köstenberger 2004:31). Die opstanding is die kulminerende genesingshandeling en teken van "God's impossibilities that shatter every contained view of reality" (Brueggemann 1995:xvii).

In Johannes word die kruis en dood van Jesus radikaal gereoriënteer en dien dit as openbarende bewys dat God, die Vader, self by Jesus en in sy sendingoptrede teenwoordig is (Van der Watt

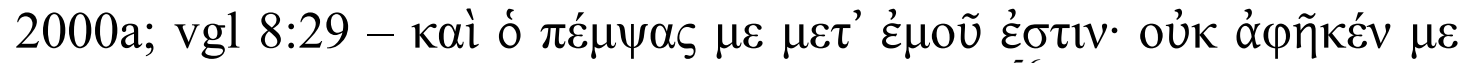
uóvov; Ridderbos 1997:304; Morris 1995:402) ${ }^{56}$. Jesus is inderdaad

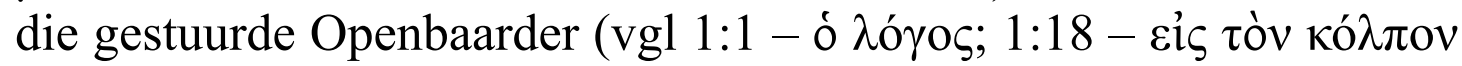

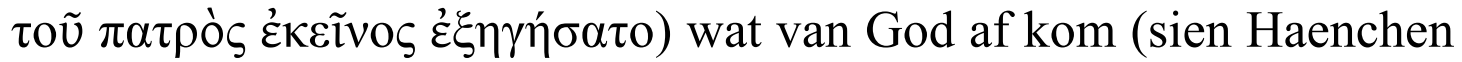
$1980: 151)$. God is by Jesus $(8: 16,29 ; 16: 32)$, Hy is in Jesus, Hy is

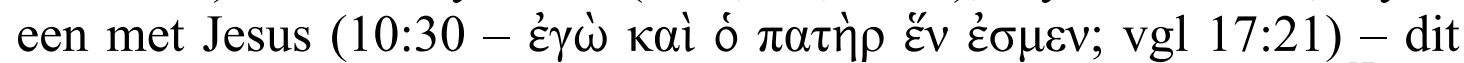
kan aan die kruis gesien word! (Schnackenburg 1971:257-258) ${ }^{57}$. So word die kruis, in die lig van die opstanding, dus primêr die openbaringsterrein vir die verhouding tussen Vader en Seun en gevolglik vir die waarheid van die totale openbaringsoptrede van

kulminerende teken in Johannes nie, maar ook die seminale teken. Met seminale teken bedoel ek dié kulminerende semeia waarop alles kulmineer maar van waaruit al die ander tekens en die sending van die Seun geïnterpreteer word. Dit neem nie weg dat Jesus se kruisdood in Johannes nie 'n krisis en vernedering en opoffering was nie. Die vernedering is egter nie die fokus nie, maar die oorwinning van die opstanding en die lewe wat daaruit vloei wat in die sentrum staan.

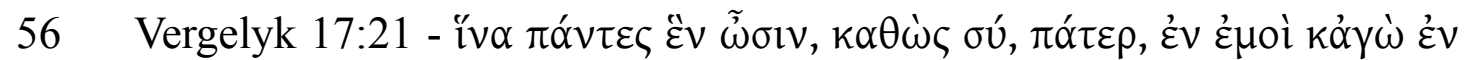

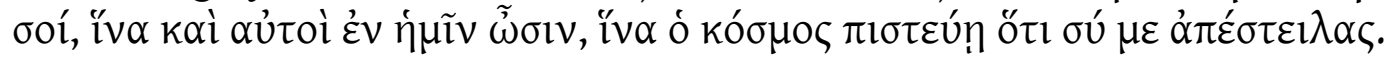

57 Schnackenburg (1971:257-258). 
Jesus (vgl $\left.3: 14^{58} ; 8: 28 ; 12: 32\right)^{59}$. Dit is dus eers deur die gereoriënteerde perspektief van die kruis dat die aardse optrede van Jesus in sy geheel, sowel as die betekenis daarvan, werklik in sy volle rykdom na vore tree $(2: 22 ; 12: 16 ; 13: 7 ; 20: 9)$.

Hierdie perspektief word veral duidelik teen die agtergrond van die feit dat die dissipels van Jesus self nie alles tydens sy lewe en werk nie (vgl 2:22; 7:37-39; 12:16; 13:7; 20:9; sien Davies 1992; Carson 1991:463) ${ }^{60}$. Eers retrospektief in die lig van die opstanding en die uitstorting van die Gees (20:22) kon die dissipels die kruis as $\delta o ́ \xi \alpha$ sien en "kon die dissipels deur pneumatiese verligting die vervlegting van die profetiese tradisies en die Jesusgebeure na waarde skat" (Van der Watt 2000a:ad loc; sien Morris 1995:180) ${ }^{61}$. Dit is dus eers na die kruisgebeure en opstanding dat die reoriëntasie kon plaasvind en die dissipels (en die wêreld) waarlik kon glo dat Jesus die gestuurde Seun van God is en so die ewige lewe kon ontvang (vgl 5:24; 6:47; 17:3; 20:30-31; sien Carson 1991:183, 661; Barrett 1978:201, 503) ${ }^{62}$. Eers ná die transformasie interaksie van die opstanding is die kruis en die dood se angel vernietig en word dit moontlik dat die gevreesde kruisdood gerepresenteer kan word as

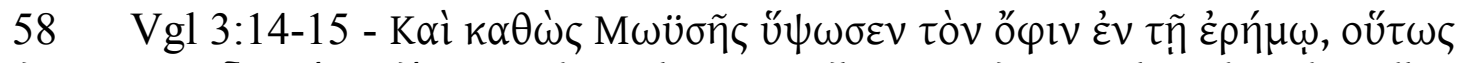

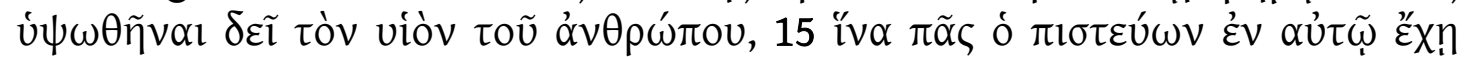

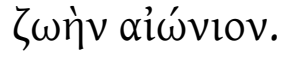

59 Bultmann (1984) en Forestell (1974) trek beide die sentrale betekenis van die dood van Jesus in die openbaringsgebeure saam. Dit is duidelik in Johannes dat die ware betekenis van Jesus aan die kruis duidelik sal word (Ridderbos 1997:303).

60 Sien Culpepper (1983:161-162) vir die misverstande in Johannes: 2:1921 ; $3: 3-5$; 4:10-15, 31-34; 6:32-35, 51-53; 7:33-36; 8:21-22, 31-35, 51-53, 56$58 ; 11: 11-15,23-25 ; 12: 32-34 ; 13: 36-38 ; 14: 4-6,7-9 ; 16: 16-19$.

61 Brown (1984:1036) argumenteer dat die gebeure in 20:22 rondom die Heilige Gees 'n hoogtepunt vorm in die post-opstandingsgebeure en is volgens hom reeds op verskeie maniere geantisipeer en voorberei in die vorige gedeelte van die hoofstuk. Hy meen dat die assosiasie van die opstanding met die hemelvaart in 20:17 en dat mense kinders van God word as Jesus terugkeer na die Vader op die werk van die Heilige Gees sinspeel. Brown (1984:1037; cf ook 949-951) gaan so ver as om te argumenteer dat die verwysing na die water en bloed wat uit Jesus se sy gevloei het, die Gees simboliseer.

62 Volgens die Joods-Hellenistiese denke (vgl Wisdom 15:3) is die kennis van die "Enigste ware God" verbind aan redding. Sien ook Philo (Special. Laws $1.60 \S 332$ ). 
koninklike magsvertoon sien Haenchen 1980:203; Schnackenburg $(1971: 367)^{63}$.

\subsubsection{Die eskatologiese era van die Gees}

Met die kruisgebeure breek die eskatologiese era van die Gees ${ }^{64}$ aan wat onmiskenbaar met die teenwoordigheid van God saamhang (Van der Watt 2000a: ad loc; sien Ridderbos 1997:276-277; vgl 7:37-39) ${ }^{65}$. Hierdie gawe van die Gees moet natuurlik in die lig van die OuTestamentiese verwagting van die lewebrengende teenwoordigheid van die Gees in die eskatologiese eindtyd gesien word, veral teen die agtergrond van die Esegiël-uitsprake, soos ons hier bo reeds aangetoon het ${ }^{66}$ (vgl Wilckens 1998:135) ${ }^{67}$.

In die gawe van die Gees deur Jesus is dit God self wat sy profetiese beloftes waar maak (Van der Watt 2000a:ad loc; sien Davies 1992:201-202; Guthrie 1970:237; Köstenberger 2004:240) ${ }^{68}$.

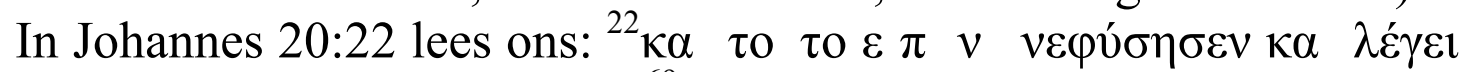

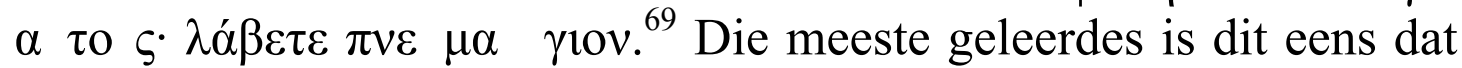

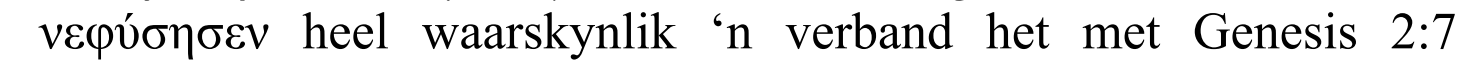

63 Carson (1991:661) en andere soos Beasley-Murray (1999:387) meen dat die dood, opstanding en verskynings van Jesus ook as Heanchen (1980:203) merk op: "Erst nach der Auferstehung Jesu haben seine Jünger den Sinn sienes rätselhaften Wortes 2,16 erfasst und diesem Wort daraufhin Glauben schenkt (der Glaube trägt sein Verstehen in sich)".

64 In 7:39 word die vloei van strome van water met die eskatologiese teenwoordigheid van die Gees verbind wat deur die Jesusgebeure 'n realiteit geword het.

65 Brown (1984:1039).

66 Hier kan byvoorbeeld aan Eseg 11:19; 18:31-32; 36:26-27; 37:1 gedink word; Kyk Jes 12:3 vir die tekste wat geassosieer is met die Tabernakel Fees (vg1 ook Sag 14:16-17); cf Köstenberger (2004:240).

67 Wilckens (1998:135): "Auch dies hat atl. Hintergrund: Nach Jes 44,3 und Ez 36,25ff. wird das Wasser der endzeitlichen Tempelquelle reinigende Wirkung haben kraft des Geistes, den Gott auf die Heilsgemeinde der Endzeit ausgessien wird. Das Gleiche wird in Sach 14,8 verheissen: 'An jenem Tage wird lebendiges Wasser aus Jerusalem herausfliessen'. Dieser Stelle entspricht Joh 7,38 im Wortlaut so deutlich, dass die Annahme sehr wahrscheinlich ist, dass Sach 14,8 zusammen mit Ps 78,15 im Blick steht."

68 Guthrie (1970:237-238).

69 Vertaling: 22 Nadat Hy dit gesê het, blaas Hy oor hulle en sê: "Ontvang die Heilige Gees!" 
(Brown 1984:1037) waar God met skeppingskrag asem of lewe in

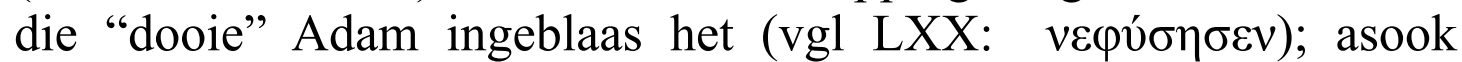

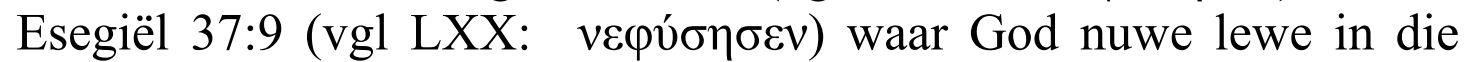
dooie (droë) beendere inblaas (Köstenberger 2004:574; Morris 1995:747; Barrett 1978:570; Brown 1970: 1035-1037). Daar beloof God sy Gees (Eseg 37:14) wat 'n dooie en verdorde volk lewendig sal maak en so vir hulle hoop, "n verwagting en nuwe lewensmoontlikhede sal gee (Eseg $37: 11)^{70}$. Hy sal ook die verstrooide volk in ' $n$ eenheid saamtrek in die beloofde land (Eseg 37:21). Hy sal hulle reinig van hulle onreinheid ${ }^{71}$ (Eseg 37:23) en hulle vir hom afsonder (Eseg 37:27-28) ${ }^{72}$. Wengst (2001:292) en ook Haenchen (1980:572) ${ }^{73}$ stem saam en merk op:

Die Formulierung vom Anhauchen erinnert an Gen 2,7, wo es von Gott im Blick auf den von ihm gebildeten Erdenkloss Adam heisst: "... und er hauchte in seine Nase Lebensodem. Da wurde Adam zum lebendigen Wesen." Nach Ez 37,9 soll der Prophet den Geist(wind) auffordern: "Komm von dem vier Winden, Geist(wind), und hauchte diese Erschlagenen an, dass sie leben." Das wird hier zum Bild fur den neuen Exodus aus dem Exil in Babel als neue Schöpfung

(Wengst 2001:292).

Die tema van nuwe lewe en die herskepping (neue Schöpfung) of realisering van verlore lewensmoontlikhede kom hier met ander woorde sterk op die voorgrond (Keener 2003:1204; Köstenberger 2004:575; Witherington 1995:342). Nie net restoureer Jesus sy eie gebrokenheid deur nuwe lewe te skep nie, maar 'blaas' of skenk ook dan hierdie lewe en lewensmoontlikhede aan die dissipels en uiteindelik die (gelowige) mensdom. Wengst (2001:292-293) merk op dat die "Gabe des Geistes und sündenvergehbung sowie neue

70 Lindars (1972:611) is daarom korrek as hy in die konteks van Johannes 20:22 opmerk: "With this symbolic action Jesus fulfills the expectation of 1.33 and the promise of the paraclete (cf also 7.39)... This suggests that John sees the constitution of the Church after the Resurrection as a kind of new creation."

71 Milgrom (1991:1005) wys op die doktrine van die priesterlike H-bron in Esegiël wat die siening handhaaf dat die onreinheid van die volk oorgedra kan word op die land sowel as die heiligdom. Om hierdie rede is daar 'n sterk fokus op heiligheid en reinheid van Israel (vgl Eseg 18:24-30; 20:22-24; 22:24).

72 Novakovic (2003:131).

73 Haenchen (1980:572). 
Schöpfung und Sündevergebung sind schon traditionell miteinander verbunden". Selfs in die konteks van Esegiël 36:25-27 handel dit oor die vergewing van sondes en die restourasie of herskepping wat

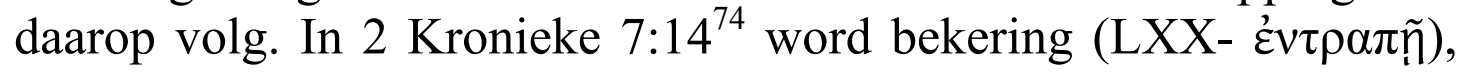
die vergifnis van sonde (LXX- $\alpha \mu \alpha \rho \tau i ́ \alpha 1 \varsigma)$ en genesing of restourasie (LXX -ió $\sigma o \mu \alpha \imath)$ eksplisiet met mekaar verbind (sien Ps 51:3-15). Rusam (2005:69) merk op dat dit in die konteks van î́ $\varepsilon$ ó $\alpha \mu \nu o ̀ \varsigma ~ \tau o \tilde{~}$

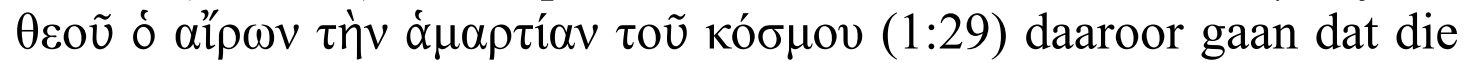

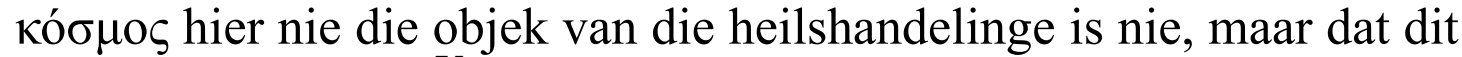
gaan om die sonde ${ }^{75}$ van die wêreld wat in fokus is - en hierdie sonde word gekwalifiseer as ongeloof. Jesus se koms en sy dood het dus te doen met die moontlikheid tot geloof, vergifnis, restourasie, herskepping en lewe in terme van 'n wêreld wat in ongeloof, sonde, dood, blindheid en spirituele gebrokenheid gedompel is (vgl 1:12, $5: 24,12: 40)^{76}$. Dit dui op nuwe lewensmoontlikhede saam en in die teenwoordigheid van die Vader en die Seun (Köstenberger 2004:426427).

Hier het ons te make met dit wat Brueggemann (1995:22) die "restorative hermeneutic of representation" noem. Nie net word die gebroke situasie gerestoureer nie, maar die disoriëntasie en verlies van lewensmoontlikhede wat daarmee saamhang word getransformeer in ' $\mathrm{n}$ situasie van verrassing, nuutheid, verplasing, reoriëntasie en ' $n$ hervoorstelling van nuwe lewensmoontlikhede (representasie). Die koms van Jesus het as't ware 'n reuse magnetiese veld in die wêreld veroorsaak en mense word of aan die positiewe of aan die negatiewe pool daarvan geposisioneer ${ }^{77}$ (Hays 1996:149 ${ }^{78}$; Guthrie 1970:238) ${ }^{79}$. Tydens 'n transformasie interaksie of ontmoeting met Jesus, vind die oordeel alreeds plaas - word

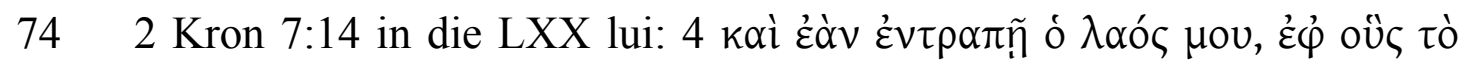

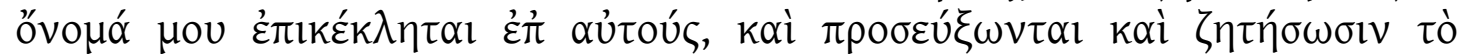

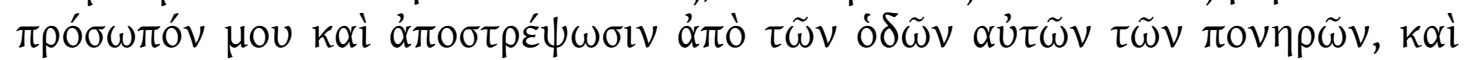

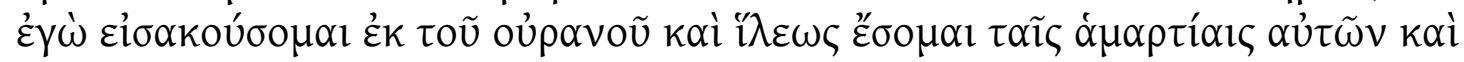

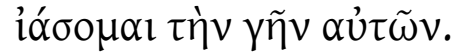

$75 \quad$ Kyk Kok (2003).

76 Vgl Morris (1995:567); Ridderbos (1997:490).

77 Barrett (1978:392).

78 Schnackenburg (1980:255).

79 Guthrie (1970:238). 
gelowiges van ongelowiges geskei ${ }^{80}$. Die wat glo is "verlig" en het alreeds oorbeweeg vanuit 'n doodsbestaan na 'n bestaanstoestand van lewe (vgl. 5:24) $)^{81}$.

Die wat nie in Jesus glo nie, en Sy status nie rekonstrueer nie, wandel in die duisternis en leuen is reeds geoordeel $(9: 39 ; 12: 47-49$; vgl Hays 1996:150) ${ }^{82}$. Hulle haat die kinders van God (15:18-25). Hulle is ewig vasgevang in ' $n$ bestaanstoestand van dood $(5: 24)$ sonder (ewige) lewensmoontlike binne God se familie. Hulle is kinders van die duiwel $(8: 44)$ op wie God se toorn rus $(3: 36)$ en het nie deel aan God se familie nie. Hulle is geestelik blind en kort genesing (12:40 - vgl ióoo $\mu \alpha)$ :

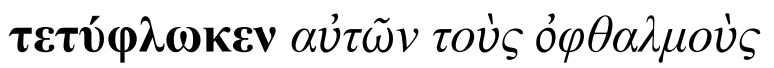

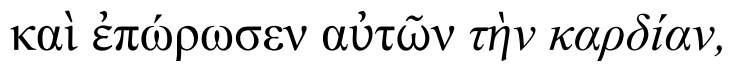

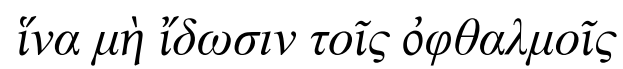

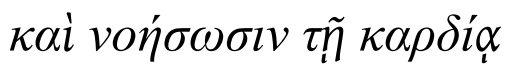

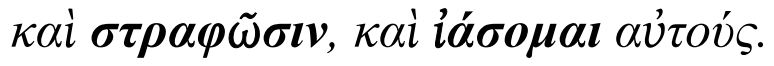

Dié wat Jesus se woorde glo en daarna luister ( $\sigma \tau \rho \alpha \varphi \tilde{\omega} \sigma \mathrm{v})$ het alreeds die ewige lewe - hulle het rééds oorbeweeg vanaf die dood

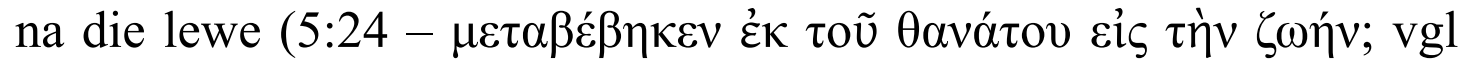
$6: 47)$ en het genesing ontvang $(12: 40$ - í́бo $\mu \alpha \imath)$. Hulle verkeer dus wesenlik in ' $n$ kwalitatiewe bestaanstoestand van lewe en gevolglike

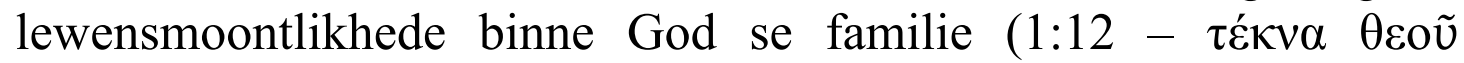
$\gamma \varepsilon v \varepsilon \dot{\varepsilon} \sigma \theta \alpha \mathrm{l})$. Die opstanding as kulminerende genesingshandeling dien in die evangelie as dié teken wat aantoon wie Jesus werklik is. Jesus is die bron van lewe $(1: 4 ; 11: 25)$ - en die wat dit glo het die ewige lewe $(3: 16 ; 20: 30-31)$. Anders gestel kan daar geargumenteer word dat die opstanding dié kulminerende $\sigma \eta \mu \varepsilon \tilde{\imath} \alpha$ is, wat nie net tot die uitstorting van die Gees lei nie (7:37-39; 20:22), maar ook lewe vir die mensdom bring (17:2-3).

Die Ou Testament gebruik self die terme "siekte" en "genesing" om na die krisis-situasie van Israel te verwys wat dikwels gekoppel is aan ongehoorsaamheid aan God (vgl 2 Kron 7:14; Jer 6:14; 8:11-12; 30:17; Hos 6:1). In Esegiël 34:1v word die

80 Sien Bultmann (1955:38).

81 Malina en Rohrbaugh (1998:196); Köstenberger (2004:188-189).

82 Schnackenburg (1980:255). 
volk Israel uitgebeeld as 'n volk wat swak, siek, beseer en verlore is. Die leiers van Israel, die wat goeie herders moes wees, het net na hulle eie belange omgesien. Hulle het nie die swakkes gehelp nie, nie die siekes gedokter nie, nie die wonde van dié wat seergekry het, versorg nie. Hulle het nie dié wat weggedwaal het, nie teruggebring nie, en nie dié wat weggeraak het, gesoek nie (Eseg 34:4). Die slegte herder-leiers van Israel word uitgebeeld as wrede regeerders (34:4) wat hul kleinvee aan wrede diere oorgelaat het (Eseg 34:5). Die goeie herder word dus uitgebeeld as " $n$ leier wat die swakkes sal help, die siekes sal genees en die wat wonde het sal versorg (Novakovic 2003:131). Uiteindelik sal die messias self die lyding en pyn van die volk dra (vgl Jes 53:4-5) ${ }^{83}$. Seybold en Müller (1978:63) merk op: "Fürwahr, unsere Krankheiten hat er getragen und unsere Schmerzen auf sich geladen; die Strafe lag auf ihm zu unserem Heil, und durch seine Wunden sind wir geheilt (Jes 53:4) ${ }^{84}$. Novakovic (2003:131) argumenteer ook oortuigend dat die metaforiese gebruik van die kategorieë siekte en genesing nie vreemd aan die $\mathrm{Ou}$ Testament is wanneer daar oor die messias of die eindtyd gedink word nie.

Vergelyk byvoorbeeld Jesaja 53:4-5 $5^{85}$

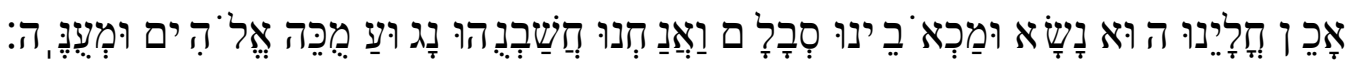

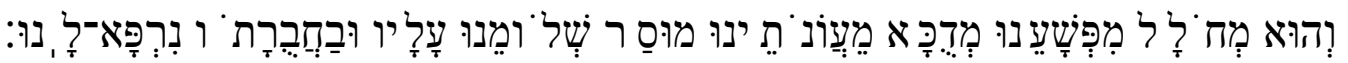

In die denke van Israel kan ons dus sien dat die dood en opstanding van Jesus op metaforiese wyse binne die kategorieë van genesing geïnterpreteer kon word omdat dit uiteindelik die "genesing" van spirituele blindheid en ongehoorsaamheid sou bring (vgl. Green et al 1992:81) $)^{86}$.

83 Seybold und Müller (1978:122) stem saam en merk op: „Alles, was Gott in dieser Welt geschlagen hat, wird er einst wieder heilen."

84 In Joh 12:37-38 haal Johannes Jes 53:1 aan, maar ontwikkel nie die teologie van die gedeelte verder soos ons dit by Matteus kry nie (vgl Mat 8:17).

85 Vertaling van Jesaja 53:4-5: 4 Tog het hy óns lyding op hom geneem, óns siektes het hy gedra. Maar ons het hom beskou as een wat gestraf word, wat deur God geslaan en gepynig word. 5 Oor ons oortredings is hy deurboor, oor óns sondes is hy verbrysel; die straf wat vir ons vrede moes bring, was op hom, deur sý wonde het daar vir ons genesing gekom.

86 Green et al (1992:81) merk op: "The Gospels, like elsewhere in biblical literature, frequently use the words blindness, deafness, eye and ear in a 


\section{SLOT}

Die opstanding as kulminerende genesingshandeling dien in die evangelie as dié teken wat aantoon wie Jesus werklik is. Die kruisgebeure (dood en opstanding) kan met ander woorde as 'n genesingshandeling beskou word aangesien dit direk saamhang met die moontlikheid wat geskep word vir geloof in Jesus en die genesing van geestelike blindheid en die verlossing van ' $n$ geestelike bestaanstoestand van dood en duisternis (vgl 5:24). Piktoraal gesproke hang die kruisgebeure onlosmaaklik saam met die verlossing van die mensdom uit ' $\mathrm{n}$ bestaanstoestand van duisternis $(\operatorname{vgl} 8: 12 ; 12: 35,46)$, dood $(5: 24)$ en verlorenheid $(3: 16)$ deur te illustreer dat Jesus inderdaad die bron van lewe is $(1: 4 ; 11: 25)$ wat mense van geestelike blindheid genees $(9: 41 ; 12: 40)$ en die vermoë het om ewige lewensmoontlikhede $(3: 16 ; 20: 30-31)$ aan mense te skenk binne die konteks van die familie van die Vader (1:12).

Die wêreld was voor die koms van Jesus volgens Johannes vasgevang in dood (5:24), duisternis en 'n sondige bestaanstoestand en verwyder van God aangesien hulle kinders van die duiwel was (vgl 8:44). Met die dood en opstanding van Jesus het dit moontlik geword dat die ganse mensdom gereoriënteer kan word tot God deur vanuit die dood na die lewe oor te gaan (vgl 5:24) en kinders van God te word (1:12). Die opstanding word op hierdie wyse ' $n$ teologie, of eerder ' $n$ simbool van hoop, wat getuig van "the claim that conventional definitions of reality do not contain or define what God will yet do in Israel” (Brueggemann 1995:xvii). In die huidige

figurative sense, conveying more than the activity of the body's sense organs. God is made known through words and deeds. To see and hear God's revelation fully requires not only physical sensation but spiritual sensitivity. It requires a personal response of understanding and commitment. Therefore, blindness and deafness can describe the inability to comprehend the spiritual truth inherent within material sights or words. This condition of hardness of heart may be due to religious or moral impairment, or due to God's intention. Salvation is frequently associated with sight in Jewish and Christian literature (Ex 14:13; 2 Chron 20:17; Ps 50:23; 91:16; 119:123; Is 40:5; 42:16-17; 59:11; 1QS 11:2-3; CD 20:34; T. Gad. 5:7; 2 Clem 1:6-7; 9:2). The OT prophets chasten the Hebrew people for having eyes and ears, and yet not seeing or hearing (Is 6:910; 43:8; Jer 5:21; Ezek 12:2). Responsibility for such spiritual blindness and deafness is sometimes said to be borne by God (Deut 29:4; Is 6:9-10) but, on the other hand, can be traced to the person's own obduracy. Yet God can overcome this hardness of heart (Is 29:18; 35:4-5; 42:6-7, 16; 61:1)." 
konteks waar ons besin oor die betekenis van die opstanding sou ons Brueggemann se woorde kon gebruik om te argumenteer dat die opstanding iets illustreer van die "coming into human experience of such impossibilities that break open every definition of reality and power. Thus the character of God contains for Israel the undeniable basis for hope against every closed system" (Brueggemann 1995:177). Die opstanding as simbool van genesing, restourasie en rekonsiliasie, binne die raamwerk van ' $n$ restouratiewe hermeneutiek van representasie, gee aan ons hoop en skep ruimte vir nuwe lewensmoontlikhede binne God se familie (1:12).

\section{Literatuurverwysings}

Barrett, C K 1978. The Gospel According to St. John. $2^{\text {nd }}$ ed. Philadelphia: Westminster Press.

Beasley-Murray, G R [1987] 1999. John. Word Biblical Commentary, vol 36. Waco, Tex.:Word.

Brown, C 1984. Miracles and the Critical mind. Grand Rapids: Eerdmans.

Brown, R E 1970. The Gospel according to John, (vol. 2), Chaps 13-21. New York: Doubleday.

-, 1972. The Gospel According to John: XIII-XXI. London: Chapman.

Brueggemann, W 1995. The Psalms and the Life of Faith. Minneapolis: Fortress Press.

Bultmann, R 1955. Theology of the New Testament. 2 vols. Trans. K Grobel. New York \& London: Scribner.

-, 1971 The Gospel of John. Philadelphia: Westminster Press.

-, 1984 Theologie des Neuen Testaments. Tübingen: Mohr.

Busse, U 2002. Das Johannesevangelium. Belgium: .Leuven University Press.

Carson, D A 1991. The Gospel according to John. Michigan: Eerdmans.

Culpepper, R A 1983. Anatomy of the Fourth Gospel: A study in literary design. Philidelphia: Fortress Press.

Davies, M 1992. Rethoric and Reference in the Fourth Gospel. Sheffield. Sheffield Academic Press.

Dietzfelbinger, C 2001. Das Evangelium nach Johannes. Zürcher Bibelkommentare. Teilband 1: Johannes 1-12. Zürich: Theologischer Verlag.

-, 2001. Das Evangelium nach Johannes. Zürcher Bibelkommentare. Teilband 2: Johannes 13-21. Zürich: Theologischer Verlag.

Dodd, C H 1960 [1953]. The Interpretation of the Fourth Gospel. Cambridge: Cambridge University Press.

Forestell, J T 1974. The Word of the Cross: Salvation as Revelation in the Fourth Gospel. Rome : Biblical Institute Press.

Gnilka, J 1983. Johannesevangelium. Würzburg: Echter Verlag.

Green, J B 1988. The death of Jesus. Tradition and interpretation in the passion narrative, WUNT 33, Tübingen: Mohr Siebeck. 
Green, J B, McKnight, S \& Marshall, I H 1992. Dictionary of Jesus and the Gospels. Downers Grove, Ill.: InterVarsity Press.

Guthrie, D 1970. New Testament Introduction. (3rd ed). England: Inter-Varsity Press.

Haenchen, E 1980. Das Johannesevangelium. Tübingen: Mohr Siebeck.

-, 1984. John (1). Hermeneia - A Critical and Historical Commentary on the Bible. Philadelphia: Fortress Press.

-, 1984. John (2). Hermeneia - A Critical and Historical Commentary on the Bible. Philadelphia: Fortress Press.

Hays, R B 1996. The Moral Vision of the New Testament. San Francisco: Harper.

Houwelingen, P H R 1997. Johannes. Het Evangelie van het Woord. Kampen: Kok.

Human, D J 2007. Bybel - pennevrug uit Antieke tyd. Die Kerkbode. 12 Oktober 2007. Deel 179 - Nommer 6.

Keener, C S 2003. The Gospel of John. 2 vols. Peabody, Mass.: Hendrikson.

Knöppler, T 1994. Die theologia crucis des Johannesevangelium. Das Verständnis des Todes Jesu im Rahmen der johaneischen Inkarnations- und erhöhungschristologie. Neukirchen-Vluyn: Neukirchener Verlag.

Kok, J 2003. 'n Eksegetiese Ondersoek na die begrip sonde in 1 Johannes. Ongepubliseerde MDiv Skripsie. Departement Nuwe Testament. Universiteit van Pretoria.

-, 2008. Siekte en Gebrokenheid teenoor Genesing en Restourasie in Johannes. Ongepubliseerde Doktorsgraad proefskrif. Departement Nuwe Testament. Pretoria: Universiteit van Pretoria.

Köstenberger, A J 2004. John. Baker Exegetical Commentary on the New Testament. Grand Rapids, Michigan. Baker Academic.

Kysar, R 1986. John. Augsburg Commentary on the New Testament, Minneapolis, Minnesota: Augsburg Publishing House.

Lincoln, A T 2005. The Gospel according to John. Black's New Testament Commentary. London: Hendrickson Publishers.

Lindars, B 1972. The Gospel of John. London: Marshall, Morgan \& Scott.

Maier, G 1984. Johannesevangelium 1. Teil. Bibelkommentar Band 6. Stuttgart: Hänsler.

Maier, G 1986. Johannesevangelium 2. Teil. Bibelkommentar Band 6. Stuttgart: Hänsler.

Malina, B J \& Rohrbaugh, R L 1992. Social-Science Commentary on the Synoptic Gospels. Minneapolis: Fortress Press.

Milgrom, J 1991. Leviticus 1-16. The Anchor Bible Dictionary. New York: Doubleday.

Moloney, F J 1998. The Gospel of John. Sacra Pagina. Harrington D J (ed.) The Liturgical Press.

Morris, L [1974] 1995. The Gospel According to John. Rev ed. Grand Rapids: Eerdmans.

Neyrey, E 1996. Despising the shame of the cross: Honor and shame in the Johannine passsion narrative in Matthews, H \& Benjamin, D C (eds), Honor and shame in the world of the Bible. Semeia 68(5), 113-137, 119-120. 
Novakovic, L 2003. Messiah, the Healer of the Sick. Tübingen: Mohr Siebeck.

Philo, O A., \& Yonge, C D [c1993] 1996. The works of Philo: Complete and unabridged (641). Peabody, MA.: Hendrickson.

Pilch, J 1991. Introducing the Cultural Context of the New Testament. New York: Paulist Press.

-, 2000. Healing in the New Testament. Insights from Medical and Mediterranean Anthropology. Minneapolis: Fortress Press.

Rahner, J 1998. Er aber sprach vom Tempel seines Leibes. Jesus von Nazaret als Ort der Offenbahrung Gottes im vierten Evangelium. Bodenheim: Philo.

Reinhartz, A 1992. The Word in the World. The Cosmological Tale in the Fourth Gospel. SBL Monograph Series 45; Atlanta: Scholars Press.

-, 2001. Befriending the Beloved Disciple. A Jewish Reading of the Gospel of John. New York: Continuum.

Ridderbos, H N [1987] 1992. The Gospel according to John: A theological commentary. Translated by J Vriend. Grand Rapids: Eerdmans.

-, 1997. The Gospel of John. Grand Rapids, Michigan/Cambridge: Eerdmans.

Rusam, D 2005. Das "Lamm Gottes" (Joh 1,29.36) und die Deutung des Todes Jesu im Johannesevangelium, 60-80. Biblische Zeitschrift 49 (2005), 60-80.

Schnackenburg, $\mathrm{R}$ [1965] 1968. The Gospel according to St John, vol. I: Introduction and commentary on chapters 1-4, translated by $\mathrm{C}$ Hastins, F McDonagh, D Smith and R Foley. London: Burns \& Oates.

-, [1971] 1980. The Gospel according to St John, vol. II: Commentary on chapters 5-12, translated by C Hastins, F McDonagh, D Smith and R Foley. London: Burns \& Oates.

-, 1971. Das Johannesevangelium. HThK 4. Freiburg: Herder.

-, 1990. The Gospel according to St. John. New York: Crossroad.

Schnelle, U 1998. Das Evangelium nach Johannes. Theologischer Handkommentar zum Neuen Testament. Leipzig: Evangelische Verlagsanstalt.

Scholtissek, K 2000. In ihm sein und bleiben: die Sprache der Immanenz in den johanneischen Schriften. Freiburg: Herder.

Seybold, K \& Müller, U B 1978. Krankheit und Heilung. Stuttgart: Kohlhammer Verlag.

Swanson, J 1997. Dictionary of Biblical Languages with Semantic Domains: Greek (New Testament) (electronic ed.) (G2615). Oak Harbor: Logos Research Systems.

Van Belle, G, Van der Watt, J G \& Maritz P (eds) 2005. Theology and Christology in the Fourth Gospel. Leuven: Leuven University Press.

Van Belle, G 2006. Glorification through Incarnation and Humiliation in the Fourth Gospel. Ongepubliseerde lesing gelewer by die Fakulteit Teologie, Universiteit van Pretoria.

Van der Watt, J G 2000a. Die Teologie van die Johannesevangelie en Briewe. Ongepubliseerde Lesing materiaal. Pretoria: Universiteit van Pretoria.

-, 2000b: Family of the King: Dynamics of Metaphor in the Gospel according to John. Leiden: Brill.

Wengst, K 2001. Das Johannesevangelium. 2. Teilband: Kapital 11-21. Kohlhammer: Stuttgart. 
Wilckens, U 1998. Das Evangelium nach Johannes. Göttingen: Vandenhoeck \& Ruprecht.

Wilkinson, J 1998. The Bible and Healing: A Medical and Theological Commentary. Grand Rapids: Eerdmans.

Witherington, B 1995. John's Wisdom: A commentary on the Fourth Gospel. Louisville: Westminster, John Knox Press. 